San Jose State University

SJSU ScholarWorks

Mineta Transportation Institute Publications

$12-2020$

\title{
Investing in California's Transportation Future: Public Opinion on Critical Needs
}

\author{
Asha Weinstein Agrawal \\ San Jose State University, asha.weinstein.agrawal@sjsu.edu \\ Hilary Nixon \\ San Jose State University, hilary.nixon@sjsu.edu \\ Cameron Simmons \\ San Jose State University
}

Follow this and additional works at: https://scholarworks.sjsu.edu/mti_publications

Part of the Infrastructure Commons, Public Policy Commons, and the Transportation Commons

\section{Recommended Citation \\ Asha Weinstein Agrawal, Hilary Nixon, and Cameron Simmons. "Investing in California's Transportation Future: Public Opinion on Critical Needs" Mineta Transportation Institute Publications (2020). https://doi.org/10.31979/mti.2020.1861}

This Report is brought to you for free and open access by SJSU ScholarWorks. It has been accepted for inclusion in Mineta Transportation Institute Publications by an authorized administrator of SJSU ScholarWorks. For more information, please contact scholarworks@sjsu.edu. 


\section{SJSU \\ $M T I / / m$}

Investing in California's Transportation Future:

Public Opinion on Critical Needs

Asha Weinstein Agrawal, PhD Hilary Nixon, PhD

Cameron Simons

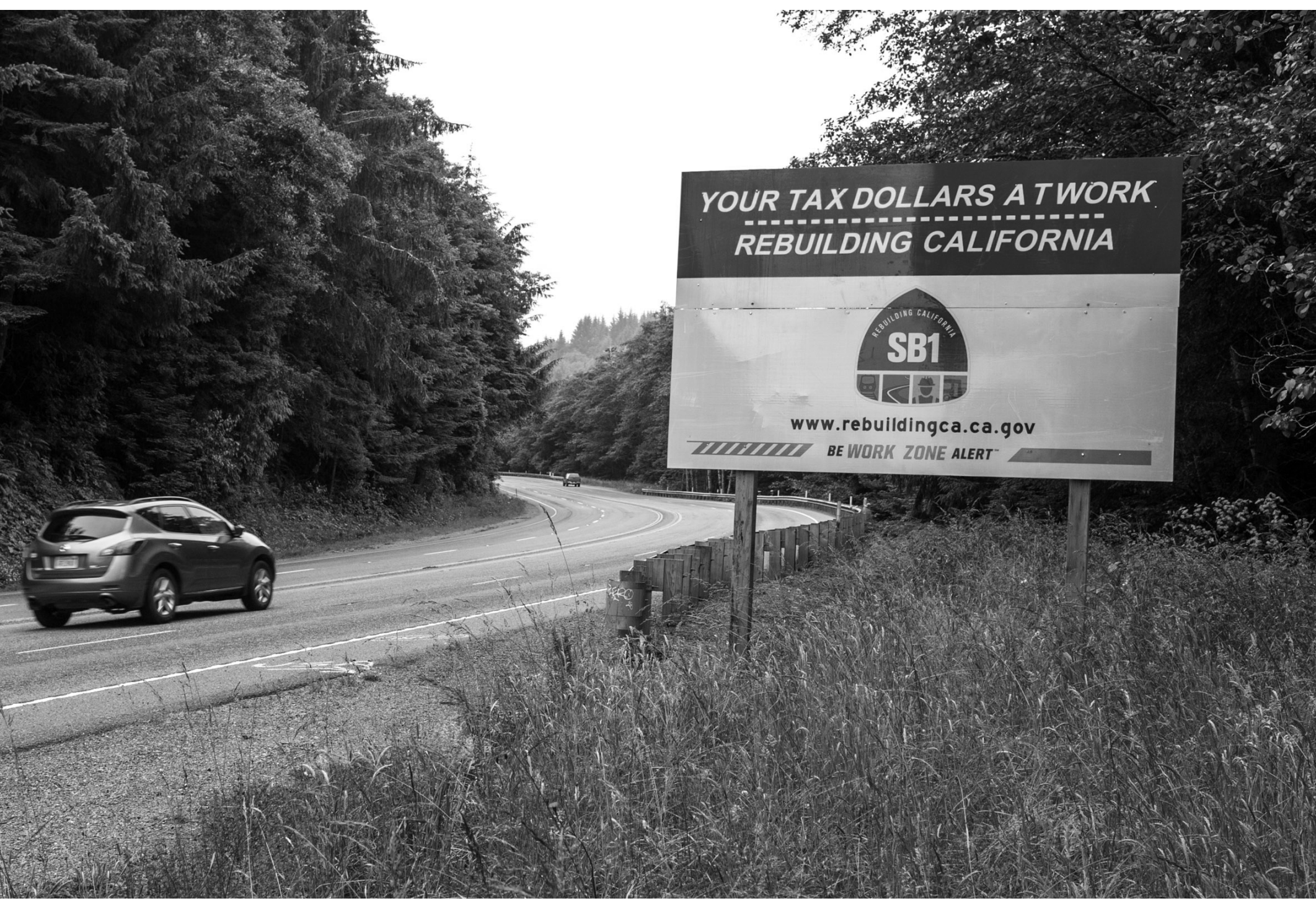




\section{MINETA TRANSPORTATION INSTITUTE}

Founded in 1991, the Mineta Transportation Institute (MTI), an organized research and training unit in partnership with the Lucas College and Graduate School of Business at San José State University (SJSU), increases mobility for all by improving the safety, efficiency, accessibility, and convenience of our nation's transportation system. Through research, education, workforce development, and technology transfer, we help create a connected world. MTI leads the Mineta Consortium for Transportation Mobility (MCTM) funded by the U.S. Department of Transportation and the California State University Transportation Consortium (CSUTC) funded by the State of California through Senate Bill I.MTI focuses on three primary responsibilities:

\section{Research}

MTI conducts multi-disciplinary research focused on surface transportation that contributes to effective decision making. Research areas include:active transportation; planning and policy; security and counterterrorism; sustainable transportation and land use; transit and passenger rail; transportation engineering; transportation finance; transportation technology; and workforce and labor. MTI research publications undergo expert peer review to ensure the quality of the research.

\section{Education and Workforce Development}

To ensure the efficient movement of people and products, we must prepare a new cohort of transportation professionals who are ready to lead a more diverse, inclusive, and equitable transportation industry. To help achieve this, MTI sponsors a suite of workforce development and education opportunities. The Institute supports educational programs offered by the Lucas Graduate School of Business: a Master of Science in Transportation Management, plus graduate certificates that include High-Speed and Intercity Rail Management and Transportation Security Management. These flexible programs offer live online classes so that working transportation professionals can pursue an advanced degree regardless of their location.

\section{Information and Technology Transfer}

MTI utilizes a diverse array of dissemination methods and media to ensure research results reach those responsible for managing change. These methods include publication, seminars, workshops, websites, social media, webinars, and other technology transfer mechanisms. Additionally, MTI promotes the availability of completed research to professional organizations and works to integrate the research findings into the graduate education program. MTI's extensive collection of transportation-related publications is integrated into San José State University's world-class Martin Luther King, Jr. Library.

\section{Disclaimer}

The contents of this report reflect the views of the authors, who are responsible for the facts and accuracy of the information presented herein. This document is disseminated in the interest of information exchange. MTl's research is funded, partially or entirely, by grants from the U.S. Department of Transportation, the U.S. Department of Homeland Security, the California Department of Transportation, and the California State University Office of the Chancellor, whom assume no liability for the contents or use thereof. This report does not constitute a standard specification, design standard, or regulation. 
REPORT 20-52

\title{
INVESTING IN CALIFORNIA'S TRANSPORTATION FUTURE: PUBLIC OPINION ON CRITICAL NEEDS
}

\author{
Asha Weinstein Agrawal, $\mathrm{PhD}$ \\ Hilary Nixon, PhD \\ Cameron Simons
}

December 2020

A publication of

Mineta Transportation Institute

Created by Congress in 1991

College of Business

San José State University

San José, CA 95192-0219 


\section{TECHNICAL REPORT DOCUMENTATION PAGE}

1. Report No. 20-52

4. Title and Subtitle

Investing in California's Transportation Future: Public Opinion on Critical Needs

2. Government Accession No.
3. Recipient's Catalog No.

5. Report Date

December 2020

6. Performing Organization Code

8. Performing Organization Report CA-MTI-1861

Asha Weinstein Agrawal, PhD

Hilary Nixon, PhD

Cameron Simons

9. Performing Organization Name and Address

Mineta Transportation Institute

College of Business

San José State University

San José, CA 95192-0219

12. Sponsoring Agency Name and Address

State of California SB1 2017/2018

Trustees of the California State

University

Sponsored Programs Administration

401 Golden Shore, 5th Floor

Long Beach, CA 90802
10. Work Unit No.

11. Contract or Grant No. ZSB12017-SJAUX

13. Type of Report and Period Covered Final Report

14. Sponsoring Agency Code

15. Supplemental Notes

DOI: $10.31979 / \mathrm{mti} .2020 .1861$

\section{Abstract}

In 2017, the State of California adopted landmark legislation to increase the funds available for transportation in the state: Senate Bill 1 (SB1), the Road Repair and Accountability Act of 2017. Through a combination of higher gas and diesel motor fuel taxes, SB1 raises revenue for four critical transportation needs in the state: road maintenance and rehabilitation, relief from congestion, improvements to trade corridors, and improving transit and rail services.

To help state leaders identify the most important projects and programs to fund within those four topical areas, we conducted an online survey that asked a sample of 3,574 adult Californians their thoughts on how the state can achieve the SB1 objectives. The survey was administered from April to August 2019 with a survey platform and panel of respondents managed by Qualtrics. Quota sampling ensured that the final sample closely reflects California adults in terms of key socio-demographic characteristics and geographic distribution.

Key findings included very strong support for improving all transportation modes, reducing air pollution and greenhouse gas emissions from transportation, and more convenient options to travel without driving. Respondents placed particular value on better maintenance for both local streets and roads, as well as highways. Finally, the majority of respondents assessed all types of transportation infrastructure in their communities as somewhat or very good.

\section{Key Words}

Public opinion, surveys, state taxation, state departments of transportation

\section{Distribution Statement}

No restrictions. This document is available to the public through

The National Technical Information Service, Springfield, VA 22161
19. Security Classif. (of this report) Unclassified
20. Security Classif. (of this page) Unclassified
21. No. of Pages

50
22. Price 


\title{
Copyright $\odot 2020$ \\ by Mineta Transportation Institute \\ All rights reserved
}

DOI: 10.31979/mti.2020.1861

\author{
Mineta Transportation Institute \\ College of Business \\ San José State University \\ San José, CA 95192-0219 \\ Tel: (408) 924-7560 \\ Fax: (408) 924-7565 \\ Email: mineta-institute@sjsu.edu
}

transweb.sjsu.edu 


\section{ACKNOWLEDGMENTS}

The authors thank the following people for their important contributions to this project:

- Student Research Assistant Alverina Weinardy for literature review assistance;

- Student Research Assistant Chenyi Luo for help producing the figures;

- Dr. Giovanni Circella, for advice on working with Qualtrics online survey panels;

- The staff at Qualtrics who assisted with survey administration;

- The 3,574 individuals who responded to the survey;

- Lisa Rose for editorial services; and

- Mineta Transportation Institute staff. 


\section{TABLE OF CONTENTS}

$\begin{array}{lr}\text { Executive Summary } & 1\end{array}$

$\begin{array}{ll}\text { I. Introduction } & 3\end{array}$

II. Methodology $\quad 4$

Questionnaire Design $\quad 4$

Survey Administration $\quad 5$

Survey Respondents $\quad 8$

$\begin{array}{ll}\text { Statistical Analysis Process } & 10\end{array}$

III. Findings: How Californians Travel 11

IV. Findings: Assessment of Transportation System Quality and Needs 13

Assessment of Transportation Infrastructure Quality 13

$\begin{array}{ll}\text { Concern about Traffic Congestion } & 17\end{array}$

$\begin{array}{ll}\text { Assessment of Transportation Agency Performance } & 17\end{array}$

V. Findings: Priorities for Spending SB1 Revenues 23

Overarching Goals for System Improvement 23

Priority Rating for Spending Options $\quad 29$

Top Spending Priorities $\quad 39$

Preferred Way to Receive SB1 Information $\quad 40$

$\begin{array}{ll}\text { VI. Conclusion } & 41\end{array}$

Ratings of the Transportation System and Agencies $\quad 41$

A Vision for Improving the Transportation System $\quad 41$

Preferences for How California Spends SB1 Revenue $\quad 41$

Appendix A: Survey Questionnaire and Topline Results 43

$\begin{array}{ll}\text { Endnotes } & 47\end{array}$

$\begin{array}{ll}\text { Abbreviations and Acronyms } & 48\end{array}$

$\begin{array}{lr}\text { Bibliography } & 49\end{array}$

$\begin{array}{ll}\text { About the Authors } & 50\end{array}$ 


\section{LIST OF FIGURES}

1. Assessment of the Quality of Transportation Infrastructure and Services in "Your Community"

2. Assessment of Transportation Agency Performance

3. Assessment of the Importance of Transportation-Related Goals for California

4. Priority Placed on Different Options for Spending SB1 Revenue

5. Options Selected as One of the Top Three Priorities for Spending SB1 Revenue

6. Preferred Way to Receive SB1 Information 


\section{LIST OF TABLES}

1. Quotas Used for Sampling

2. Comparison of Survey Respondents to the Adult California Population by Caltrans District and Sociodemographic Characteristics

3. Percent of Respondents Who Used Different Travel Modes Within the Last 30 Days

4. Percent of Respondents With a Mobility Impairment Limiting Their Ability to Use Specific Travel Modes

5. Respondents' Annual Mileage Driven

6. Fuel Efficiency of Respondents' Primary Vehicle

7. Percent of Respondents with a Positive Assessment of the Quality of the Transportation System, by Demographics

8. Percent of Respondents with a Positive Assessment of the Quality of the Transportation System, by Travel Behavior

9. Percent of Respondents with a Positive Assessment of the Quality of the Transportation System, by Geography

10. Percent of Respondents with a Positive Assessment of the Quality of the Transportation System, by Political Affiliation

11. Percent of Respondents Rating Government Agencies as Doing a Good Job, by Socio-Demographics

12. Percent of Respondents Rating Government Agencies as Doing a Good Job, by Travel Behavior

13. Percent of Respondents Rating Government Agencies as Doing a Good Job, by Geography

14. Percent of Respondents Rating Government Agencies as Doing a Good Job, by Political Affiliation

15. Percent of Respondents Rating Government Agencies as Doing a Good Job, by Assessment of Transportation System Quality

16. Percent of Respondents Rating Transportation-Related Goals for California as Important, by Socio-Demographics 
17. Percent of Respondents Rating Transportation-Related Goals for California as Important, by Geography

18. Percent of Respondents Rating Transportation-Related Goals for California as Important, by Political Affiliation

19. Percent of Respondents Rating Transportation-Related Goals for California as Important, by Travel Behavior

20. Percent of Respondents Identifying Spending Priorities as Important, by Socio-Demographic Characteristics

21. Percent of Respondents Identifying Spending Priorities as Important, by Travel Behavior

22. Percent of Respondents Identifying Spending Priorities as Important, by Geography

23. Percent of Respondents Identifying Spending Priorities as Important, by Political Affiliation

24. Percent of Respondents Identifying Spending Priorities as Important, by Assessment of the Transportation System and Agencies 


\section{EXECUTIVE SUMMARY}

In 2017, the State of California adopted landmark legislation to increase the funds available for transportation in the state: Senate Bill 1 (SB1), the Road Repair and Accountability Act of 2017. Through a combination of higher gas and diesel motor fuel taxes, SB1 raises revenue for four critical transportation needs in the state: road maintenance and rehabilitation, relief from congestion, improvements to trade corridors, and improving transit and rail services.

This research project is designed to help state leaders identify the most important projects and programs to fund within those four topical areas. To do so, we conducted an online survey in 2019 that asked a random sample of 3,574 adult Californians their thoughts on how the state can achieve the SB1 objectives. By understanding California residents' opinions related to these issues, policymakers can shape programs and policies to meet the needs identified by the public. The study results are also useful to local and regional agencies planning their future transportation programs.

\section{STUDY METHODS}

The survey questionnaire probed respondents about how they assess the current state of transportation infrastructure and systems and the government agencies that provide these, their high-level priorities for how the transportation system can be improved, and what specific programs they would prefer to see funded with SB1 revenues. In addition, we asked how respondents would prefer that the state communicate with them about SB1 expenditures. Finally, the survey also asked standard socio-demographic questions, simple travel behavior questions, home zip code and city, and community type (urban, suburban, small-town, rural) so that the responses can be analyzed by these all factors.

The survey was administered online with a survey platform and panel of respondents managed by Qualtrics. Quota sampling was used to ensure a sample that closely represented the California adult population in terms of gender, race and ethnicity, employment status, annual household income, and age. A total of 3,574 California adults responded with usable data.

\section{FINDINGS}

The primary study findings cluster into three main topics: how respondents rated transportation in their community, their broad goals for improving transportation, and their preferences for how California spends SB1 revenues.

Three key findings relate to how respondents rated the transportation system in their community and the state and local agencies that manage transportation:

1. The majority of respondents rated all transportation infrastructure and servicesstate highways, local streets, public transit, and bicycle/pedestrian infrastructureas at least "somewhat good."

2. Most respondents were at least "somewhat concerned" about traffic congestion. 
3. The majority of respondents rated the performance of transportation agencies as at least "somewhat good," with the highest approval for Caltrans.

The survey also revealed what kinds of broad goals respondents had for improving transportation in California:

4. Virtually all respondents wanted to see improvements to all modes, reductions in air pollution and greenhouse gas emissions from transportation, and more convenient options to travel without driving.

The third set of findings relate to how respondents wanted to see SB1 revenues spent:

5. Supermajorities supported each of the 11 spending options presented, including options that relate to roads and highways, public transit, and encouraging electric vehicles.

6. The public saw highway and local street maintenance as top priorities.

7. Modestly more people prioritized maintenance of local streets and roads than maintenance of highways.

8. For both highways and local streets, maintenance was a top priority for considerably more people than was expansion.

9. Most respondents supported transit-related spending improvements, but these were a top priority for only small minorities.

10. The least popular spending options related to electric vehicles, though even these options were rated positively by a supermajority.

11. Most respondents would find it "useful" to get information about how SB1 money is spent via monthly emails and/or as inserts in annual vehicle registration notices mailed by the state's Department of Motor Vehicles (DMV). 


\section{INTRODUCTION}

In 2017, the State of California adopted landmark legislation to increase the funds available for transportation in the state: Senate Bill 1 (SB1), the Road Repair and Accountability Act of 2017. Through a combination of higher gas and diesel motor fuel taxes, SB1 raises revenue for four critical transportation needs in the state: road maintenance and rehabilitation, relief from congestion, improvements to trade corridors, and improving transit and rail services.

This research project is designed to help state leaders identify the most important projects and programs to fund within those four topical areas. To do so, we conducted an online survey in 2019 that asked a random sample of 3,574 adult Californians their thoughts on how the state can achieve the SB1 objectives. By understanding California residents' opinions related to these issues, policymakers can shape programs and policies to meet the needs identified by the public. The study results are also useful to local and regional agencies planning their future transportation programs.

The survey questionnaire probed respondents about four topics:

- How they assess the current state of transportation infrastructure and systems, as well as performance by the government agencies that provide these

- Their high-level priorities for how the transportation system can be improved

- The specific programs they would prefer to see funded with SB1 revenues

- How they would prefer that the state communicates with them about SB1 expenditures

The survey also asked respondents to rate the quality of the transportation system and agencies managing it, plus standard socio-demographic questions, simple travel behavior questions, home zip code and city, and community type (urban, suburban, small-town, rural).

The remainder of the report is organized as follows:

- Chapter 2 describes the survey methodology, including questionnaire design, sampling and survey administration, and the statistical tests used for data analysis.

- Chapter 3 presents findings on how Californians travel.

- Chapter 4 presents findings on how Californians assess transportation system quality and needs.

- Chapter 5 presents their priorities for how to spend SB1 revenue and how they receive information about SB1 expenditures.

- Chapter 6 concludes the report with a summary of key findings that suggest opportunities for state leaders to craft spending programs directly targeting the types of improvements that the public prioritizes. 


\section{METHODOLOGY}

The online survey was completed by 3,574 California adults. This chapter describes the questionnaire design, survey sampling and administration, and characteristics of the respondents.

\section{QUESTIONNAIRE DESIGN}

The underlying research goal was to understand California residents' preferences for how SB1 funds are allocated, as well as to assess if different preferences were associated with socio-demographic characteristics, travel behaviors, and opinions. In addition, the questionnaire probed respondents about how they assess the current state of transportation infrastructure and systems and the government agencies that provide these, as well as how respondents would prefer that the state communicates with them about SB1 expenditures.

This primary objective was addressed with a series of four questions about California residents' goals for the transportation system, the ways they thought funds should be spent, and how they would like the state government to share updates on how SB1 revenue has been spent.

The first of these questions asked respondents to rate the importance of six different overarching goals for the transportation system. For each, respondents chose "very important," "somewhat important," or "not at all" important. The goals were:

- Reduce traffic congestion

- Reduce crashes and improve safety for everyone

- Reduce health impacts caused by air pollution from cars and trucks

- Reduce greenhouse gas emissions from transportation sources that contribute to climate change

- Maintain and improve roads, streets, highways, and bridges

- Make it more convenient to go places without driving (bus, walk, bike, etc.)

Second, respondents were asked to rate the priority they would place on 13 different ways that the state could spend SB1 revenues. Respondents rated the priority for each as a high, medium, low, or "not at all," and also selected the three options from the list that they thought were most important. The options presented for this pair of questions were:

- Build/improve sidewalks

- Subsidize public transit fares for low-income people 
- Develop programs that encourage people to switch from driving their cars to walking, biking, or using transit

- Provide financial incentives for people to purchase electric vehicles (EVs)

- Build/improve bike lanes and bike paths

- Use advanced technologies to reduce congestion and increase reliability

- Install more charging stations for electric vehicles

- Add more frequent public transit service on existing routes

- Expand public transit service into new areas not already served

- Maintain local streets and roads

- Build/widen local roads and streets

- Build/widen highways and freeways

- Maintain highways and freeways

Finally, a fourth question asked respondents how they would like to have the state share updates about how the money is spent. Respondents rated each of four options as "very useful," "somewhat useful," or "not at all" useful.

The other sections of the survey gathered data on respondents' opinions about the condition of the transportation system, the travel modes they had used in the previous 30 days, their annual miles driven and the fuel efficiency of the vehicle they drove most often, the type of community they lived in (urban, suburban, small town, or rural), political affiliation, and standard socio-demographic characteristics (gender, age, Hispanic ethnicity, race, ${ }^{1}$ education, employment status, and annual household income).

The exact wording used for all questions can be found in Appendix A, which reproduces the survey questionnaire.

\section{SURVEY ADMINISTRATION}

The survey was administered online with a survey platform and panel of respondents managed by Qualtrics. Online surveys are increasingly popular, in part due to their low cost, the speed at which they can be administered, convenience for respondents, and the ability to include question design options that are difficult or impossible to implement via telephone or mail. ${ }^{2}$ A 2019 analysis from the Pew Research Center found that $90 \%$ of Americans are online,$^{3}$ which suggests that online surveys are currently a reasonable method to reach a representative sample of U.S. adults, despite evidence that some population subgroups are often underrepresented in online surveys. Less well-represented groups include people who 
are older, low-income, have less formal education, live in rural communities, and do not have high-speed internet access at home. ${ }^{4}$

Quota sampling was used to ensure the respondents would closely represent the California adult population, including groups that are typically less well represented with online surveys. We requested a sample closely representative of California adults, as defined by U.S. American Community Survey (ACS) data on gender, race and ethnicity, employment status, annual household income, and age. In addition, to ensure that the sample was geographically diverse, we set quotas based on population by Caltrans districts. Table 1 shows all quotas for the sample. 
Table 1. Quotas Used for Sampling

\begin{tabular}{|c|c|c|}
\hline & & $(\%)^{a}$ \\
\hline \multirow[t]{12}{*}{ Caltrans District } & District 1: North Coast & 2 \\
\hline & District 2: Redding and Northern California & 2 \\
\hline & District 3: Sacramento/Chico & 8 \\
\hline & District 4: Bay Area & 18 \\
\hline & District 5: Central Coast & 4 \\
\hline & District 6: Fresno/Northern San Joaquin Valley & 7 \\
\hline & District 7: Los Angeles/Ventura & 25 \\
\hline & District 8: San Bernardino/Riverside & 12 \\
\hline & District 9: Mono/Inyo & 1 \\
\hline & District 10: Stockton/Northern San Joaquin Valley & 5 \\
\hline & District 11: San Diego/Imperial & 9 \\
\hline & District 12: Orange County & 8 \\
\hline \multirow[t]{2}{*}{ Gender } & Male & 50 \\
\hline & Female & 50 \\
\hline Of Hispanic/Latino origin/descent & & 39 \\
\hline \multirow[t]{4}{*}{ Race } & White only & 65 \\
\hline & Black/African-American only & 7 \\
\hline & Asian/Asian-American only & 16 \\
\hline & Other, including multiracial & 16 \\
\hline \multirow[t]{9}{*}{ Income (annual household) } & $\$ 0-\$ 4,999$ & 4 \\
\hline & $\$ 5,000-\$ 9,999$ & 4 \\
\hline & $\$ 10,000-\$ 24,999$ & 17 \\
\hline & $\$ 25,000-\$ 49,999$ & 20 \\
\hline & $\$ 50,000-\$ 74,999$ & 16 \\
\hline & $\$ 75,000-\$ 99,999$ & 12 \\
\hline & $\$ 100,000-\$ 149,999$ & 14 \\
\hline & $\$ 150,000-\$ 199,999$ & 7 \\
\hline & $\$ 200,000$ or more & 7 \\
\hline \multirow[t]{6}{*}{ Age (years) } & $18-24$ & 14 \\
\hline & $25-44$ & 35 \\
\hline & $45-64$ & 31 \\
\hline & $65-74$ & 11 \\
\hline & $75-84$ & 6 \\
\hline & $85+$ & 3 \\
\hline
\end{tabular}

a Percentages for quotas were based on population values for California from the American Community Survey.

Respondents completed the survey between April 15 and August 13, 2019. The median time to complete each survey was 6.5 minutes, and the mean time was ten minutes. A total of 3,574 California adults responded with usable data. Qualtrics does not recommend calculating response or frequency rates because their sampling method does not track how many people ever received an invitation. 


\section{SURVEY RESPONDENTS}

The 3,574 survey respondents were generally representative of the California population in terms of geography (Caltrans district) and sociodemographic characteristics (Table 2). For the survey findings and analysis presented in this report, we lightly weighted the data using a raking method to match the Census Bureau's 2017 American Community Survey five-year estimates for California adults with respect to gender, race, Hispanic ethnicity, ${ }^{a}$ education level, household income, and age. ${ }^{5}$ 
Table 2. Comparison of Survey Respondents to the Adult California Population by Caltrans District and Sociodemographic Characteristics

\begin{tabular}{|c|c|c|c|}
\hline & & $\begin{array}{c}\text { Sample, } \\
\text { unweighted (\%) }\end{array}$ & $\begin{array}{c}\text { California } \\
\text { adults }^{a}(\%)\end{array}$ \\
\hline \multirow[t]{12}{*}{ Caltrans district } & District 1: North Coast & 2 & 1 \\
\hline & District 2: Redding and NorCal & 1 & 1 \\
\hline & District 3: Sacramento/Chico & 8 & 7 \\
\hline & District 4: Bay Area & 18 & 20 \\
\hline & District 5: Central Coast & 4 & 4 \\
\hline & District 6: Fresno/Northern San Joaquin Valley & 7 & 7 \\
\hline & District 7: Los Angeles/Ventura & 25 & 28 \\
\hline & District 8: San Bernardino/Riverside & 12 & 11 \\
\hline & District 9: Mono/Inyo & 1 & $<1$ \\
\hline & District 10: Stockton/N. San Joaquin Valley & 5 & 4 \\
\hline & District 11: San Diego/Imperial & 8 & 9 \\
\hline & District 12: Orange County & 8 & 8 \\
\hline \multirow[t]{3}{*}{ Gender } & Male & 43 & 50 \\
\hline & Female & 56 & 50 \\
\hline & Other & $1^{\mathrm{b}}$ & $--^{c}$ \\
\hline Of Hispanic/Latino origin/descent & & 38 & 39 \\
\hline \multirow[t]{4}{*}{ Race } & White only & 70 & 65 \\
\hline & Black/African-American only & 6 & 7 \\
\hline & Asian/Asian-American only & 13 & 16 \\
\hline & Other, including multiracial & 11 & 18 \\
\hline \multirow[t]{5}{*}{ Education } & Less than high school graduate & 2 & 17 \\
\hline & High school graduate & 17 & 22 \\
\hline & Some college & 36 & 32 \\
\hline & College graduate & 29 & 19 \\
\hline & Graduate degree & 16 & 11 \\
\hline \multirow[t]{3}{*}{ Employment status } & Working for pay & 68 & 58 \\
\hline & Unemployed but looking for work & 6 & 5 \\
\hline & Not working for pay, by choice (retired, etc.) & 27 & 37 \\
\hline \multirow[t]{9}{*}{ Income (annual household) } & $\$ 0-\$ 4,999$ & 5 & 4 \\
\hline & $\$ 5,000-\$ 9,999$ & 3 & 3 \\
\hline & $\$ 10,000-\$ 24,999$ & 11 & 15 \\
\hline & $\$ 25,000-\$ 49,999$ & 20 & 20 \\
\hline & $\$ 50,000-\$ 74,999$ & 16 & 16 \\
\hline & $\$ 75,000-\$ 99,999$ & 14 & 12 \\
\hline & $\$ 100,000-\$ 149,999$ & 16 & 14 \\
\hline & $\$ 150,000-\$ 199,999$ & 8 & 7 \\
\hline & $\$ 200,000$ or more & 8 & 9 \\
\hline
\end{tabular}


Table 2, continued

\begin{tabular}{lccc}
\hline & $\begin{array}{c}\text { Sample, } \\
\text { unweighted (\%) }\end{array}$ & $\begin{array}{c}\text { California } \\
\text { adultsa }(\%)\end{array}$ \\
\hline Age (years) & $18-24$ & 13 & 14 \\
& $25-44$ & 40 & 35 \\
$45-64$ & 32 & 31 \\
$65-74$ & 11 & 11 \\
$75-84$ & 4 & 6 \\
$85+$ & $<1$ & 3 \\
\hline a All data are for California adults 18 years and older, with the exception of household income, which is for all \\
California households. Caltrans district population statistics from U.S. Census Bureau: https://www.census.gov/ \\
popclock/data tables.php?component=growth. All other population data from ACS 2017 5-Year Estimates. \\
b Due to small sample size, the 26 respondents who stated "other" are not included in the analyses on gender in this \\
report. \\
c The ACS questionnaire restricts answer options to male or female. \\
Note: Some percentages do not sum to 100\% due to rounding.
\end{tabular}

\section{STATISTICAL ANALYSIS PROCESS}

For each topic, we looked at how responses differed by socio-demographic factors, characteristics of the place the respondent lives (geography), political affiliation, and travel behavior. This analysis used the statistical test of two proportions to check whether differences among subgroups (e.g., men versus women) are statistically significant at the $95 \%$ and $99 \%$ confidence levels. Tables 7 through 24 present the results from this statistical testing. For each set of population categories (i.e., male vs. female or do vs. do not use transit), the first subgroup listed is the reference case against which the other subgroups are compared.

Readers should note that the statistically significant differences among subgroups identified in the tables are not necessarily the only important differences that exist. Rather, the highlighted differences are those that were statistically significant according to the particular statistical tests used. It is also important to keep in mind that statistical significance is not an automatic indicator of scientific or policy importance, as discussed in a 2016 statement from the American Statistical Association. ${ }^{6}$

The following chapters highlight those variations by subgroups that were not only statistically significant but also of large enough magnitude to suggest meaningful differences. The criterion selected to identify "meaningful" differences is statistically significant differences of at least ten percentage points. 


\section{FINDINGS: HOW CALIFORNIANS TRAVEL}

The survey asked simple travel behavior questions in order to identify what modes respondents used, their level of driving, and the type of vehicle they drove.

Respondents indicated all travel modes they had used in the past 30 days (Table 3 ). Travel by private car as a driver or passenger were the most common responses, though a high percentage had also walked to get somewhere. Eighty-six percent of respondents had driven themselves, and $74 \%$ had ridden as a passenger. As for walking, $72 \%$ had done so for transportation purposes. Modes all used by roughly one-third of respondents were public transit (41\%), ride-sharing (38\%), and bicycling (30\%). Taxis were used by only $17 \%$, closely followed by use of micromobility devices such as electric kick-scooters and skateboards (16\%).

Table 3. Percent of Respondents Who Used Different Travel Modes Within the Last 30 Days

\begin{tabular}{ll}
\hline Travel mode & $\%$ \\
\hline Drive yourself (car, truck, motorcycle, etc.) & 86 \\
Ride as a passenger in a personal vehicle (exclude trips in taxis, rideshare like Uber/Lyft, etc.) & 74 \\
Walk to get somewhere (a store, work, friend's house, etc.) & 72 \\
Public transit (bus, train, ferry, etc.) & 41 \\
Ridesharing services like Uber or Lyft & 38 \\
Bicycle to get somewhere (a store, work, friend's house, etc.) & 30 \\
Taxi & 17 \\
Electric kick-scooter, skateboard, or other small device & 16 \\
Other & 11 \\
\hline
\end{tabular}

The survey asked respondents whether they had a mobility impairment limiting their ability to use the main modes. Just under one-fourth had limitations to walking and biking, $13 \%$ had limitations related to using transit, and $12 \%$ had impairments that limited their ability to drive.

Table 4. Percent of Respondents With a Mobility Impairment Limiting Their Ability to Use Specific Travel Modes

\begin{tabular}{ll}
\hline Travel mode & $\%$ \\
\hline Walk & 24 \\
Bike & 23 \\
Drive & 12 \\
Transit & 13 \\
\hline
\end{tabular}

To get a sense of driving intensity and fuel use, respondents were asked to estimate both how many miles they drove annually for personal use and the fuel efficiency of the vehicle they drove most often. As Table 5 shows, roughly one-fifth did not drive at all (19\%). For those who reported driving, the mean value was around 11,000 miles annually, and the median was 8,000 miles annually. About a quarter (24\%) drove quite little, at no more than 3,000 miles per year, while at the other extreme, $18 \%$ drove 13,000 or more miles per year. 
As for vehicle efficiency, Table 6 shows that about one-third drove quite inefficient vehicles getting no more than $21 \mathrm{mpg}(28 \%), 42 \%$ drove moderately or very efficient vehicles getting 22 to $43 \mathrm{mpg}$, and only $9 \%$ drove the most efficient vehicles (at least $44 \mathrm{mpg}$ ) or electric vehicles (EVs). Finally, 19\% did not drive at all.

Table 5. Respondents' Annual Mileage Driven

\begin{tabular}{ll}
\hline Annual mileage & $\%$ \\
\hline $1-3,000$ miles & 24 \\
$3,001-9,000$ miles & 20 \\
$9,001-13,000$ miles & 19 \\
$13,001+$ miles & 18 \\
Don't drive & 19 \\
\hline
\end{tabular}

Note: For those who reported any driving, the mean value was 11,116 miles, and the median was 8,000 miles.

Table 6. Fuel Efficiency of Respondents' Primary Vehicle

\begin{tabular}{lc}
\hline Fuel efficiency & $\%$ \\
\hline$<=16 \mathrm{mpg}$ & 12 \\
$17-21 \mathrm{mpg}$ & 16 \\
$22-28 \mathrm{mpg}$ & 24 \\
$29-43 \mathrm{mpg}$ & 18 \\
$44+\mathrm{mpg}$ and EVs & 9 \\
Don't know & 21 \\
\hline
\end{tabular}




\section{FINDINGS: ASSESSMENT OF TRANSPORTATION SYSTEM QUALITY AND NEEDS}

\section{ASSESSMENT OF TRANSPORTATION INFRASTRUCTURE QUALITY}

Respondents assessed the quality of transportation infrastructure and services in their community in terms of state highways, public transit, bicycle and pedestrian facilities, and local streets and roads (Figure 1). Although less than 20\% rated any of these as "very good," few people were highly critical. The percentages of "very bad" ratings ranged from just $7 \%$ to $13 \%$. The majority gave positive ratings of either "somewhat good" or "very good" for state highways (68\%), public transit $(61 \%)$, and bicycle and pedestrian facilities $(60 \%)$. Fewer respondents rated local streets and roads as somewhat or very good, though this was still the majority $(53 \%)$.

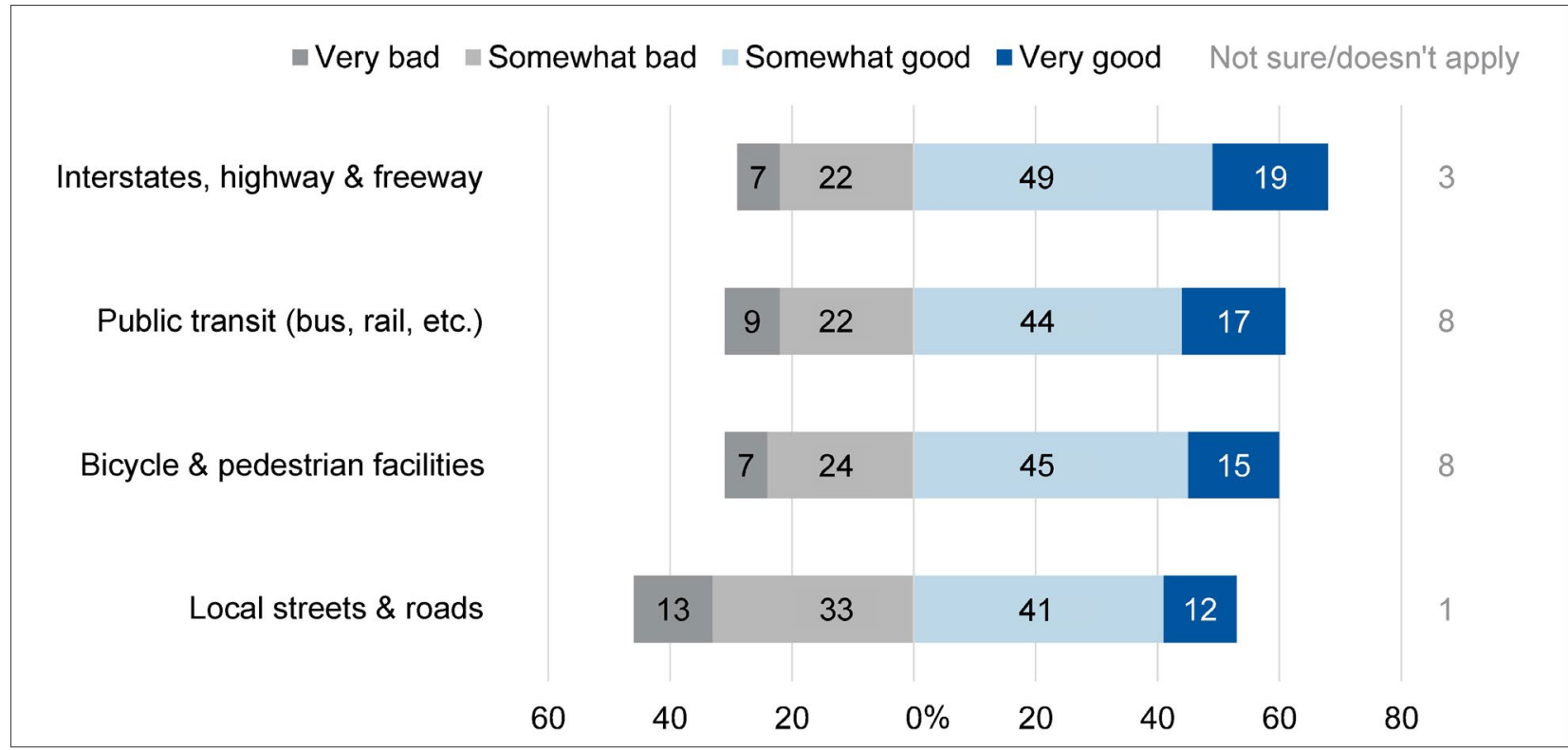

Figure 1. Assessment of the Quality of Transportation Infrastructure and Services in "Your Community"

Note: NS/DA means "Not sure/doesn't apply"

For the various assessments of transportation performance, we looked at whether opinions varied by demographics, political affiliation, geography, and travel behavior (see Tables 7-10). There were very few notable differences, especially for state highways. Across all four types of infrastructure, there were no notable differences by gender, race, employment status, or having walked or used ridehailing in the preceding 30 days. Across the other subgroups, there were scattered differences with no particular pattern. 


\section{Table 7. Percent of Respondents with a Positive Assessment ${ }^{\mathrm{a}}$ of the Quality of the Transportation System, by Demographics}

\begin{tabular}{|c|c|c|c|c|}
\hline & State highways & Local roads & $\begin{array}{l}\text { Bike/pedestrian } \\
\text { infrastructure }\end{array}$ & $\begin{array}{l}\text { Public } \\
\text { transit }\end{array}$ \\
\hline \multicolumn{5}{|l|}{ Gender } \\
\hline Male & 68 & 55 & 63 & 61 \\
\hline Female & 68 & $51^{* *}$ & $58^{* *}$ & 60 \\
\hline \multicolumn{5}{|l|}{ Of Hispanic/Latino origin/descent } \\
\hline Yes & 70 & 53 & 60 & 67 \\
\hline No & $67^{*}$ & 53 & 61 & $56^{* *}$ \\
\hline \multicolumn{5}{|l|}{ Race } \\
\hline White only & 68 & 53 & 60 & 59 \\
\hline Black/African-American only & 67 & 54 & 66 & 60 \\
\hline Asian/Asian-American only & 69 & 55 & 63 & 58 \\
\hline Other, including multiracial & 70 & $47^{*}$ & $54^{*}$ & 63 \\
\hline \multicolumn{5}{|l|}{ Education } \\
\hline High school or less & 67 & 51 & 55 & 64 \\
\hline Some college & 68 & 52 & $63^{* *}$ & 63 \\
\hline College graduate & 69 & $57^{* *}$ & $64^{* *}$ & $54^{* *}$ \\
\hline \multicolumn{5}{|l|}{ Employment status } \\
\hline Working for pay & 68 & 54 & 62 & 61 \\
\hline Unemployed but looking for work & $76^{* * \mathrm{~b}}$ & 58 & 62 & $68^{*}$ \\
\hline Not working for pay, by choice (retired, etc.) & 66 & $49^{* *}$ & $56^{* *}$ & $57^{* c}$ \\
\hline \multicolumn{5}{|l|}{ Income (annual household) } \\
\hline$\$ 0-\$ 49,999$ & 68 & 51 & 56 & 64 \\
\hline$\$ 50,000-\$ 99,999$ & 68 & 50 & $64^{* *}$ & 61 \\
\hline$\$ 100,000-\$ 149,999$ & 71 & $61^{* * d}$ & $67^{* *}$ & 59 \\
\hline$\$ 150,000$ or more & 68 & $61^{* *}$ e & $64^{* *}$ & $48^{* \star f}$ \\
\hline \multicolumn{5}{|l|}{ Age (years) } \\
\hline $18-24$ & 75 & 57 & 62 & 60 \\
\hline $25-44$ & $68^{* *}$ & 53 & 58 & 63 \\
\hline $45-64$ & $63^{* *}$ & $52^{*}$ & 62 & 62 \\
\hline $65+$ & 70 & $50^{*}$ & 61 & $53^{* * g}$ \\
\hline
\end{tabular}

Note: The test of two proportions was used to check if there is a statistically significant difference between support levels among subgroups. The first subgroup in each category is the reference case against which the proportion of respondents in other subgroups is compared. Values in yellow cells are at least ten percentage points different from the reference case.

${ }^{*}$ Statistically significant at $p<0.05 .{ }^{* *}$ Statistically significant at $p<0.01$.

a Sum of respondents stating "very" or "somewhat" good.

b Statistically significantly different $(p<0.01)$ by ten percentage points from respondents not working for pay by choice.

c Statistically significantly different $(p<0.01)$ by ten percentage points from respondents unemployed but looking for work.

d Statistically significantly different $(p<0.01)$ by at least ten percentage points from respondents in households with annual income of $\$ 50,000-\$ 99,999$.

e Statistically significantly different $(p<0.01)$ by at least ten percentage points from respondents in households with annual income of $\$ 50,000-\$ 99,999$.

f Statistically significantly different $(p<0.01)$ by at least ten percentage points from respondents in all other income groups.

9 Statistically significantly different $(p<0.01)$ by at least ten percentage points from respondents 25 to 44 years old. 
Table 8. Percent of Respondents with a Positive Assessment ${ }^{\mathrm{a}}$ of the Quality of the Transportation System, by Travel Behavior

\begin{tabular}{|c|c|c|c|c|}
\hline & State highways & Local roads & Bike/pedestrian infrastructure & Public transit \\
\hline \multicolumn{5}{|l|}{ Transit use } \\
\hline Used in last 30 days & 70 & 57 & 63 & 66 \\
\hline Not used in last 30 days & 67 & $50^{* *}$ & $59^{* *}$ & $56^{* *}$ \\
\hline \multicolumn{5}{|l|}{ Walk } \\
\hline Used in last 30 days & 69 & 54 & 61 & 63 \\
\hline Not used in last 30 days & 66 & $49^{* *}$ & 58 & $54^{* *}$ \\
\hline \multicolumn{5}{|l|}{ Bicycle } \\
\hline Used in last 30 days & 72 & 64 & 65 & 66 \\
\hline Not used in last 30 days & $67^{* *}$ & $48^{* *}$ & $58^{* *}$ & $58^{* *}$ \\
\hline \multicolumn{5}{|l|}{ Ridehail (i.e., Uber/Lyft) } \\
\hline Used in last 30 days & 69 & 57 & 62 & 62 \\
\hline Not used in last 30 days & 68 & $51^{* *}$ & 60 & 60 \\
\hline \multicolumn{5}{|l|}{ E-scooter, skateboard, etc. } \\
\hline Used in last 30 days & 70 & 62 & 61 & 57 \\
\hline Not used in last 30 days & 68 & $52^{* *}$ & 60 & 61 \\
\hline \multicolumn{5}{|l|}{ Annual miles driven } \\
\hline $1-3,000$ & 69 & 52 & 60 & 65 \\
\hline $3,001-9,000$ & 69 & 53 & 59 & $55^{* *}$ \\
\hline $9,001-13,000$ & 69 & 50 & $65^{*}$ & $59^{*}$ \\
\hline $13,001+$ & 65 & 53 & 63 & $56^{* *}$ \\
\hline Don't drive & 68 & 56 & $55^{\mathrm{b}}$ & $66^{d}$ \\
\hline \multicolumn{5}{|l|}{ Miles per gallon } \\
\hline$\leq 16$ & 70 & 54 & 62 & 67 \\
\hline $17-21$ & $62^{*}$ & 49 & 60 & $55^{* *}$ \\
\hline $22-28$ & 69 & 50 & 63 & $55^{\star *}$ \\
\hline $29-43$ & 69 & 53 & 64 & $61^{*}$ \\
\hline $44+($ or EV) & $80^{* * \mathrm{C}}$ & $69^{* * c}$ & 66 & 60 \\
\hline Don't know & 66 & $47^{*}$ & 59 & 62 \\
\hline
\end{tabular}

Note: The test of two proportions was used to check if there is a statistically significant difference between support levels among subgroups. The first subgroup in each category is the reference case against which the proportion of respondents in other subgroups is compared. Values in yellow cells are at least ten percentage points different from the reference case.

* Statistically significant at $p<0.05$. ** Statistically significant at $p<0.01$.

a Sum of respondents stating "very" or "somewhat" good.

b A statistically significant difference $(p<0.01)$ of at least ten percentage points from respondents who drove 9,00113,000 miles annually.

c A statistically significant difference $(p<0.01)$ of at least ten percentage points from respondents in all other mileage sub-groups.

d A statistically significant difference $(p<0.01)$ of at least ten percentage points from respondents who drove 3,0019,000 annually and respondents who drove more than 13,001 miles annually. 


\section{Table 9. Percent of Respondents with a Positive Assessment ${ }^{\mathrm{a}}$ of the Quality of the Transportation System, by Geography}

\begin{tabular}{|c|c|c|c|c|}
\hline & State highways & Local roads & Bike/pedestrian infrastructure & Public transit \\
\hline \multicolumn{5}{|l|}{ Regions $^{b}$} \\
\hline Northern California & 65 & 45 & 55 & 59 \\
\hline Bay Area & 63 & $52^{*}$ & 58 & 60 \\
\hline Central Coast/Central Valley & $61^{\mathrm{c}}$ & 47 & $66^{* *}$ & 54 \\
\hline Los Angeles Metro Area & $73^{* *}$ & $61^{* * d}$ & $63^{* *}$ & $65^{\star} \mathrm{e}$ \\
\hline San Diego/Inland Empire & $72^{* *}$ & $51^{*}$ & 58 & 61 \\
\hline \multicolumn{5}{|l|}{ Urban form (self-reported) } \\
\hline Urban & 68 & 53 & 60 & 68 \\
\hline Suburban & 68 & 55 & $65^{* *}$ & $58^{* *}$ \\
\hline Small town or rural & 69 & $48^{*}$ & $54^{* * f}$ & $55^{\star *}$ \\
\hline
\end{tabular}

Note: The test of two proportions was used to check if there is a statistically significant difference between support levels among subgroups. The first subgroup in each category is the reference case against which the proportion of respondents in other subgroups is compared. Values in yellow cells are at least ten percentage points different from the reference case.

${ }^{*}$ Statistically significant at $p<0.05 .{ }^{* *}$ Statistically significant at $p<0.01$.

a Sum of respondents stating "very" or "somewhat" good.

b Regions are defined as follows: Northern California includes Caltrans District 1, Caltrans District 2, and Caltrans District 3; Bay Area includes Caltrans District 4; Central Coast/Central Valley includes Caltrans District 5, Caltrans District 6, Caltrans District 9, and Caltrans District 10; Los Angeles Metro Area includes Caltrans District 7 and Caltrans District 12; San Diego/Inland Empire includes Caltrans District 8 and Caltrans District 11.

c Statistically significantly different $(p<.01)$ by at least ten percentage points from respondents in the Los Angeles and San Diego regions.

d Statistically significantly different $(p<.01)$ by at least ten percentage points from respondents in the Bay Area and San Diego regions.

e Statistically significantly different $(p<.01)$ by at least ten percentage points from respondents in the Bay Area.

f Statistically significantly different $(p<.01)$ by eleven percentage points from suburban respondents.

\section{Table 10. Percent of Respondents with a Positive Assessment ${ }^{\mathrm{a}}$ of the Quality of the Transportation System, by Political Affiliation}

\begin{tabular}{lcccc}
\hline & State highways & Local roads & Bike/pedestrian infrastructure & Public transit \\
\hline Republican/lean Republican $^{\mathrm{b}}$ & 69 & 56 & 64 & 57 \\
Democrat/lean Democratic $^{\mathrm{c}}$ & 68 & $51^{*}$ & 62 & $63^{* *}$ \\
Some other party $^{\mathrm{d}}$ & 67 & 60 & 66 & 54 \\
Independent (no party affiliation) $^{*}$ & 68 & $50^{* \mathrm{e}}$ & $51^{\text {* } \mathrm{f}}$ & 60 \\
\hline
\end{tabular}

Note: The test of two proportions was used to check if there is a statistically significant difference between support levels among subgroups. The first subgroup in each category is the reference case against which the proportion of respondents in other subgroups is compared. Values in yellow cells are at least ten percentage points different from the reference case.

* Statistically significant at $p<0.05 .{ }^{* *}$ Statistically significant at $p<0.01$.

a Sum of respondents stating "very" or "somewhat" good.

b Includes respondents who considered themselves a Republican or "lean" towards the Republican Party.

c Includes respondents who considered themselves a Democrat or "lean" towards the Democratic Party.

d Respondents who considered themselves some other party (not Republican, Democrat, or independent).

e Statistically significantly different $(p<.05)$ by at least ten percentage points from "some other party."

f Statistically significantly different $(p<.01)$ by at least ten percentage points from respondents identifying with all parties. 


\section{CONCERN ABOUT TRAFFIC CONGESTION}

The survey also asked respondents if they were concerned about traffic congestion in their community, and the great majority $(86 \%)$ were at least "somewhat" concerned. Forty-four percent were "very concerned," $42 \%$ "somewhat concerned," and only $14 \%$ "not at all concerned."

An analysis of how different subgroups rated their concern about congestion ${ }^{7}$ revealed no notable differences at all by socio-demographic characteristics or political affiliation, but some by travel choices and geography. There was notably less concern among people who do not drive; $79 \%$ who did not drive were concerned, as compared to people who drove 9,001 to 13,000 miles per year $(90 \%)$ or more than 13,000 miles per year $(89 \%)$. Also, people living in the more rural regions (Northern California and the Central Coast/Central Valley) were less concerned than people living in the more urban regions of the Bay Area, Los Angeles Metro Area, and San Diego/Inland Empire. Echoing that finding, people who lived in self-identified small towns or rural communities were less likely to be concerned than people living in urban and suburban communities.

\section{ASSESSMENT OF TRANSPORTATION AGENCY PERFORMANCE}

When asked to rate the performance of different government agencies involved in transportation, the findings tracked those for the assessment of infrastructure and services themselves: the majority rated all three as either "somewhat good" or "very good," though more people approved of Caltrans (65\%) and public transit agencies $(64 \%)$ than local city and county governments (54\%).

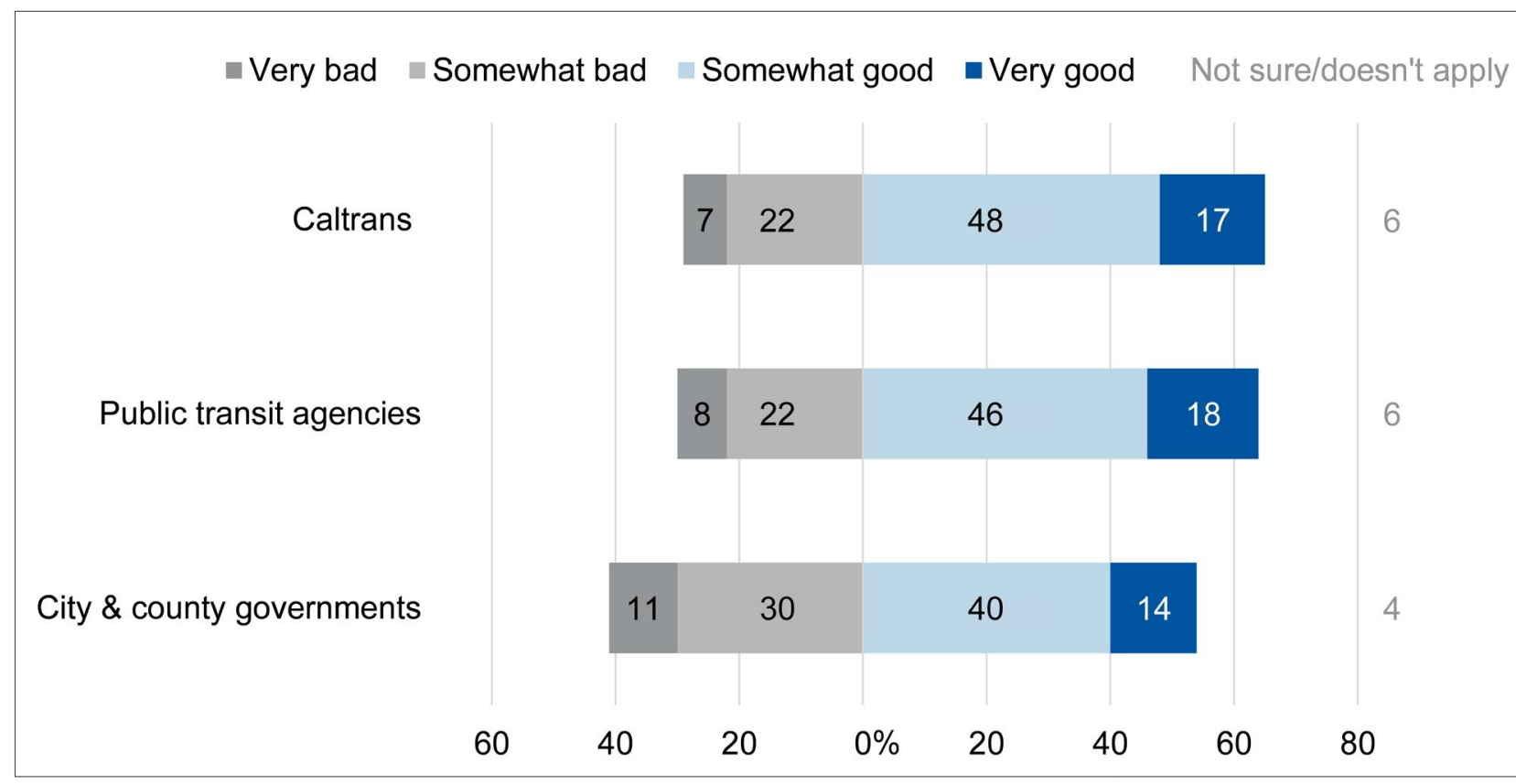

Figure 2. Assessment of Transportation Agency Performance Note: NS/DA means "Not sure/doesn't apply" 
For the assessment of performance, we looked at how responses varied among subgroups defined by opinions regarding the quality of the transportation system, as well as those defined by socio-demographics, geography, travel behavior, and political affiliation (Tables 11 to 15). Several cross-cutting patterns stand out with respect to sub-groups that met our criteria for meaningful variation, a statistically significant difference of at least ten percentage points:

- There were no meaningful differences by gender, education, having used public transit in the preceding 30 days, annual miles driven, or political party.

- Respondents who rated the quality of state highways, local roads, bicycle and pedestrian infrastructure, or public transit as "somewhat good" or "very good" were notably more likely to rate all three types of government agencies as doing a good job.

- The only variations among how sub-groups rated Caltrans were higher ratings by people who rated the quality of state highways, local roads, bicycle and pedestrian infrastructure, or public transit as "somewhat good" or "very good." 


\section{Table 11. Percent of Respondents Rating Government Agencies as Doing a Good Job $^{\text {a }}$, by Socio-Demographics}

\begin{tabular}{|c|c|c|c|}
\hline & $\begin{array}{c}\text { Caltrans } \\
(\%)\end{array}$ & $\begin{array}{c}\text { Public transit agencies } \\
(\%)\end{array}$ & $\begin{array}{c}\text { City and county government } \\
(\%)\end{array}$ \\
\hline \multicolumn{4}{|l|}{ Gender } \\
\hline Male & 65 & 63 & 54 \\
\hline Female & 66 & 65 & 55 \\
\hline \multicolumn{4}{|l|}{ Of Hispanic/Latino origin/descent } \\
\hline Yes & 69 & 74 & 57 \\
\hline No & $62^{* *}$ & $57^{\star *}$ & $52^{\star *}$ \\
\hline \multicolumn{4}{|l|}{ Race } \\
\hline White only & 65 & 62 & 52 \\
\hline Black/African-American only & 68 & 64 & $59^{*}$ \\
\hline Asian/Asian-American only & $58^{*}$ & 57 & 58 \\
\hline Other, including multiracial & 67 & $73^{* * b}$ & 51 \\
\hline \multicolumn{4}{|l|}{ Education } \\
\hline High school or less & 65 & 65 & 54 \\
\hline Some college & 67 & 67 & 55 \\
\hline College graduate & 64 & $59^{* *}$ & 54 \\
\hline \multicolumn{4}{|l|}{ Employment status } \\
\hline Working for pay & 66 & 68 & 57 \\
\hline $\begin{array}{l}\text { Unemployed but looking for } \\
\text { work }\end{array}$ & 71 & $73^{*}$ & 62 \\
\hline $\begin{array}{l}\text { Not working for pay, by choice } \\
\text { (retired, etc.) }\end{array}$ & $61^{* * c}$ & $55^{\star \star c}$ & $47^{\star \star c}$ \\
\hline \multicolumn{4}{|l|}{ Income (annual household) } \\
\hline$\$ 0-\$ 49,999$ & 66 & 68 & 54 \\
\hline$\$ 50,000-\$ 99,999$ & 65 & $62^{* *}$ & 52 \\
\hline$\$ 100,000-\$ 149,999$ & 66 & $62^{*}$ & 56 \\
\hline$\$ 150,000$ or more & 62 & $55^{\star *}$ & 58 \\
\hline \multicolumn{4}{|l|}{ Age (years) } \\
\hline $18-24$ & 64 & 68 & 60 \\
\hline $25-44$ & 67 & 70 & 60 \\
\hline $45-64$ & 65 & $61^{* *}$ & $51^{\star \star}$ \\
\hline $65+$ & 62 & $52^{* \star d}$ & $42^{* * d}$ \\
\hline
\end{tabular}

Note: The test of two proportions was used to check if there is a statistically significant difference between support levels among subgroups. The first subgroup in each category is the reference case against which the proportion of respondents in other subgroups is compared. Values in yellow cells are at least ten percentage points different from the reference case.

${ }^{*}$ Statistically significant at $p<0.05 .{ }^{* *}$ Statistically significant at $p<0.01$.

a Sum of respondents stating "very" and "somewhat" good.

b Statistically significantly difference $(p<.01)$ of at least ten percentage points from Asian/Asian-American respondents.

c Statistically significantly difference $(p<.01)$ of at least ten percentage points from unemployed respondents.

d Statistically significantly difference $(p<.01)$ of at least ten percentage points from respondents 25 to 44 years old. 


\section{Table 12. Percent of Respondents Rating Government Agencies as Doing a Good Joba $^{a}$, by Travel Behavior}

\begin{tabular}{|c|c|c|c|}
\hline & $\begin{array}{l}\text { Caltrans } \\
(\%)\end{array}$ & $\begin{array}{l}\text { Public transit agencies } \\
(\%)\end{array}$ & $\begin{array}{c}\text { City and county government } \\
(\%)\end{array}$ \\
\hline \multicolumn{4}{|l|}{ Transit use } \\
\hline Used in last 30 days & 65 & 69 & 58 \\
\hline Not used in last 30 days & 65 & $61^{* *}$ & $52^{* *}$ \\
\hline \multicolumn{4}{|l|}{ Walk } \\
\hline Used in last 30 days & 66 & 67 & 56 \\
\hline Not used in last 30 days & $62^{*}$ & $56^{* *}$ & $49^{* *}$ \\
\hline \multicolumn{4}{|l|}{ Bicycle } \\
\hline Used in last 30 days & 69 & 70 & 66 \\
\hline Not used in last 30 days & $64^{* *}$ & $62^{* *}$ & $49^{* *}$ \\
\hline \multicolumn{4}{|l|}{ Ridehail (i.e. Uber/Lyft) } \\
\hline Used in last 30 days & 66 & 67 & 59 \\
\hline Not used in last 30 days & 64 & $62^{* *}$ & $51^{\star \star}$ \\
\hline \multicolumn{4}{|c|}{$\begin{array}{l}\text { Electric kick-scooter, skateboard, other small } \\
\text { device }\end{array}$} \\
\hline Used in last 30 days & 64 & 69 & 69 \\
\hline Not used in last 30 days & 65 & $63^{* *}$ & $52^{* *}$ \\
\hline \multicolumn{4}{|l|}{ Annual miles driven } \\
\hline $1-3,000$ & 66 & 68 & 55 \\
\hline $3,001-9,000$ & 68 & $59^{\star *}$ & 50 \\
\hline $9,001-13,000$ & 63 & $60^{* *}$ & 51 \\
\hline $13,001+$ & 67 & 64 & 60 \\
\hline Don't drive & $61^{*}$ & 67 & 55 \\
\hline \multicolumn{4}{|l|}{ Miles per gallona } \\
\hline$\leq 16$ & 72 & 74 & 62 \\
\hline $17-21$ & $63^{* *}$ & $57^{* *}$ & $47^{* *}$ \\
\hline $22-28$ & $64^{\star *}$ & $58^{* *}$ & $48^{\star *}$ \\
\hline $29-43$ & 67 & $66^{*}$ & $54^{*}$ \\
\hline $44+($ or EV) & $64^{*}$ & 75 & $71^{*}$ \\
\hline Don't know & $66^{*}$ & $62^{* *}$ & $55^{*}$ \\
\hline
\end{tabular}

Note: The test of two proportions was used to check if there is a statistically significant difference between support levels among subgroups. The first subgroup in each category is the reference case against which the proportion of respondents in other subgroups is compared. Values in yellow cells are at least ten percentage points different from the reference case.

* Statistically significant at $p<0.05 .{ }^{* *}$ Statistically significant at $p<0.01$.

a Sum of respondents rating the agency as "very" and "somewhat" good.

b Statistically significant difference from all mileage subgroups except the 29-43 mpg subgroup. 


\section{Table 13. Percent of Respondents Rating Government Agencies as Doing a Good Joba , by Geography}

\begin{tabular}{lccc}
\hline & $\begin{array}{c}\text { Caltrans } \\
(\%)\end{array}$ & $\begin{array}{c}\text { Public transit agencies } \\
(\%)\end{array}$ & $\begin{array}{c}\text { City and county government } \\
(\%)\end{array}$ \\
\hline Regions $^{b}$ & & & 45 \\
$\quad$ Northern California & 61 & 58 & $57^{* *}$ \\
Bay Area & $67^{*}$ & $66^{* *}$ & 51 \\
Central Coast/Central Valley & $57^{c}$ & 60 & $59^{* *}$ \\
Los Angeles Metro Area & $67^{*}$ & $66^{\star *}$ & $52^{*}$ \\
San Diego/Inland Empire & $69^{* *}$ & $65^{\star *}$ & 58 \\
Urban form (self-reported) & & & 55 \\
Urban & 65 & 66 & $47^{* *}$ \\
Suburban & 65 & 63 & \\
Small town or rural & 66 & 66 & \\
\hline
\end{tabular}

Note: The test of two proportions was used to check if there is a statistically significant difference between support levels among subgroups. The first subgroup in each category is the reference case against which the proportion of respondents in other subgroups is compared. Values in yellow cells are at least ten percentage points different from the reference case.

* Statistically significant at $p<0.05 .{ }^{* *}$ Statistically significant at $p<0.01$.

a Sum of respondents stating "very" and "somewhat" good.

b Regions are defined as follows: Northern California includes Caltrans District 1, Caltrans District 2, and Caltrans District 3; Bay Area includes Caltrans District 4; Central Coast/Central Valley includes Caltrans District 5, Caltrans District 6, Caltrans District 9, and Caltrans District 10; Los Angeles Metro Area includes Caltrans District 7 and Caltrans District 12; San Diego/Inland Empire includes Caltrans District 8 and Caltrans District 11.

c A statistically significant difference at $p<0.01$ of at least ten percentage points from respondents in all other regions except Northern California.

\section{Table 14. Percent of Respondents Rating Government Agencies as Doing a Good Joba , by Political Affiliation}

\begin{tabular}{lccc}
\hline & $\begin{array}{c}\text { Caltrans } \\
(\%)\end{array}$ & $\begin{array}{c}\text { Public transit agencies } \\
(\%)\end{array}$ & $\begin{array}{c}\text { City and county government } \\
(\%)\end{array}$ \\
\hline Republican/lean Republican $^{\mathrm{b}}$ & 64 & 62 & 53 \\
Democrat/lean Democratic $^{\mathrm{c}}$ & 67 & $67^{*}$ & 56 \\
Some other party $^{\mathrm{d}}$ & 69 & 65 & $62^{*} \mathrm{e}$ \\
Independent, no party affiliation $^{\mathrm{e}}$ & 61 & 61 & 51 \\
\hline
\end{tabular}

Note: The test of two proportions was used to check if there is a statistically significant difference between support levels among subgroups. The first subgroup in each category is the reference case against which the proportion of respondents in other subgroups is compared. Values in yellow cells are at least ten percentage points different from the reference case.

* Statistically significant at $p<0.05$.

a Sum of respondents rating the agency as "very" and "somewhat" good.

b Respondents who considered themselves a Republican or "lean" towards the Republican Party.

c Includes respondents who considered themselves a Democrat or "lean" towards the Democratic Party.

d Respondents who considered themselves some other party (not Republican, Democrat, or independent).

e Statistically significantly different from "Independents" at $p<.01$. 


\section{Table 15. Percent of Respondents Rating Government Agencies as Doing a Good Job $^{a}$, by Assessment of Transportation System Quality}

\begin{tabular}{llcc}
\hline & $\begin{array}{c}\text { Caltrans } \\
(\%)\end{array}$ & $\begin{array}{c}\text { Public transit agencies } \\
(\%)\end{array}$ & $\begin{array}{c}\text { City and county government } \\
(\%)\end{array}$ \\
\hline $\begin{array}{l}\text { Quality of state highways } \\
\text { Very/somewhat good }\end{array}$ & 75 & 72 & 66 \\
$\begin{array}{l}\text { Very/somewhat bad } \\
\text { Quality of local roads } \\
\text { Very/somewhat good }\end{array}$ & $45^{\star *}$ & $49^{* *}$ & $31^{* *}$ \\
Very/somewhat bad & 76 & 72 & 73 \\
$\begin{array}{l}\text { Quality of bike/pedestrian infrastructure } \\
\text { Very/somewhat good }\end{array}$ & $53^{* *}$ & $55^{* *}$ & $33^{* *}$ \\
Very/somewhat bad & 74 & 75 & 65 \\
Quality of public transit & $51^{* *}$ & $52^{* *}$ & $38^{* *}$ \\
Very/somewhat good & & & 63 \\
Very/somewhat bad & 74 & 82 & $41^{* *}$ \\
\hline
\end{tabular}

Note: The test of two proportions was used to check if there is a statistically significant difference between support levels among subgroups. The first subgroup in each category is the reference case against which the proportion of respondents in other subgroups is compared. Values in yellow cells are at least ten percentage points different from the reference case.

** Statistically significant at $p<0.01$.

a Sum of respondents rating the agency as "very" and "somewhat" good. 


\section{FINDINGS: PRIORITIES FOR SPENDING SB1 REVENUES}

The primary research objective was to understand California residents' preferences for how SB1 funds are allocated, as well as to assess whether different preferences were associated with socio-demographic characteristics, travel behaviors, and opinions. This chapter presents findings from four questions that directly address this topic: respondents' goals for the transportation system, the ways they thought funds should be spent, and how they would like to receive updates on how SB1 revenue has been spent.

\section{OVERARCHING GOALS FOR SYSTEM IMPROVEMENT}

To learn what vision Californians have for how to improve the transportation system, the survey asked respondents to rate the priority they thought the state government should place on each of six possible goals for improving the transportation system. As Figure 3 shows, all six proved almost universally popular, with at least $90 \%$ of respondents rating each goal as "somewhat important" or "very important." The three most popular options were maintaining and improving roads, streets, highways, and bridges (98\%), reducing crashes and improving safety for everyone (97\%), and reducing traffic congestion (97\%).

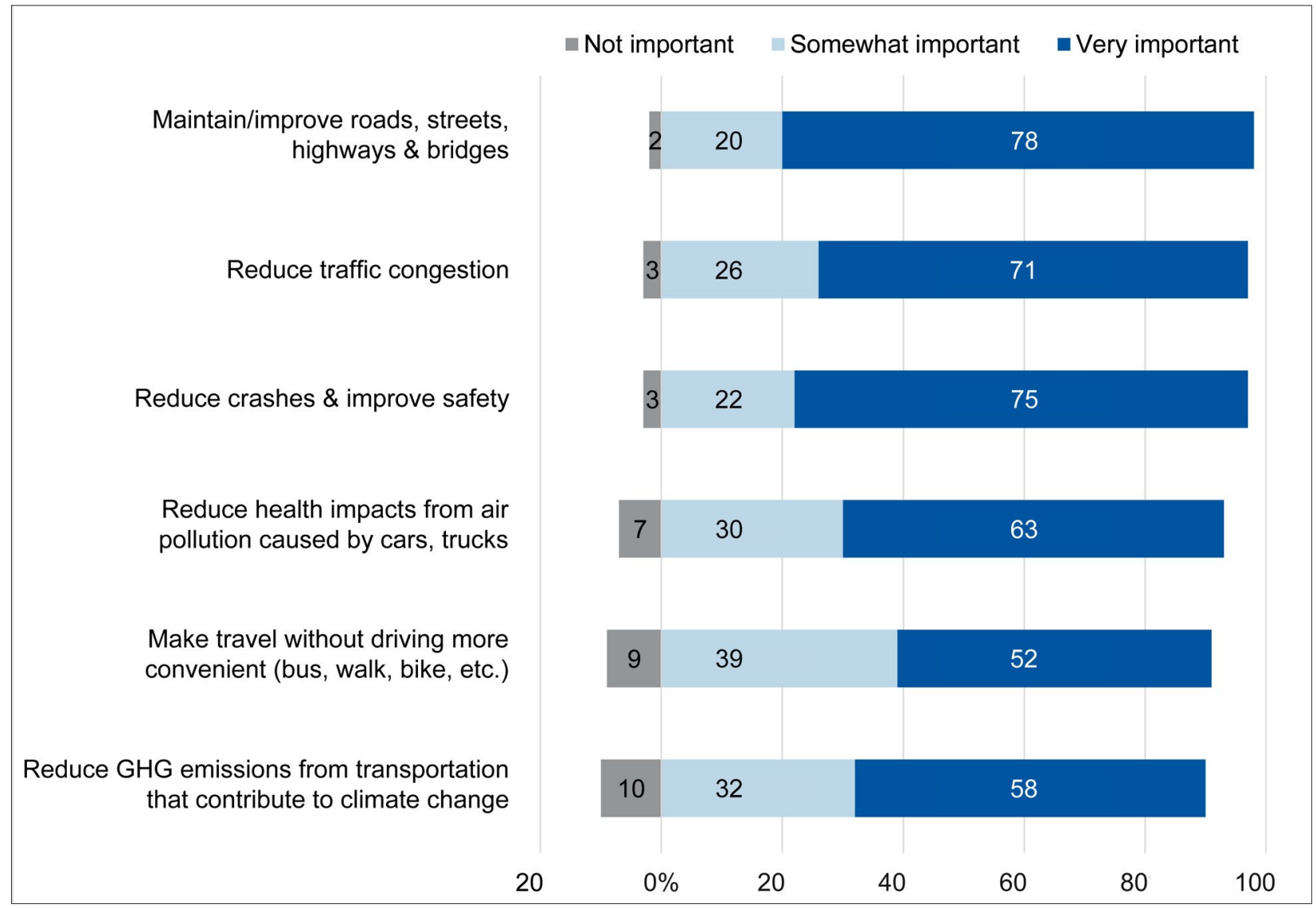

Figure 3. Assessment of the Importance of Transportation-Related Goals for California 
Reflecting the near-universal importance placed on the six goals, the analysis by subgroup found virtually no statistically significant differences of at least ten percentage points for any goal (Tables 16 through 19). However, one exception was that Democratic-leaning respondents and party-independent respondents were more likely than Republicanleaning respondents to rate reducing green-house gas emissions as "somewhat important" or "very important." Also, the goal of making it more convenient to go places without driving was supported by larger proportions of Democratic-leaning respondents and respondents living in the Central Coast/Central Valley. 
Table 16. Percent of Respondents Rating Transportation-Related Goals for California as Important ${ }^{a}$, by Socio-Demographics

\begin{tabular}{|c|c|c|c|c|c|c|}
\hline & 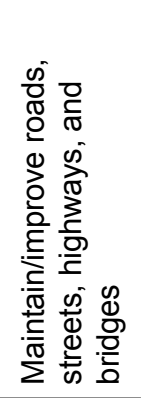 & 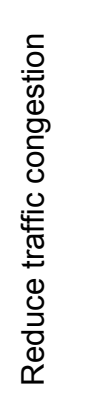 & 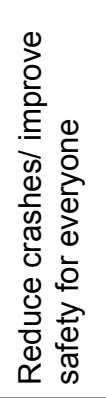 & 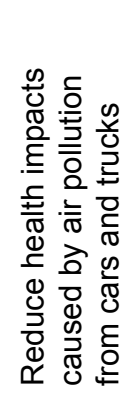 & 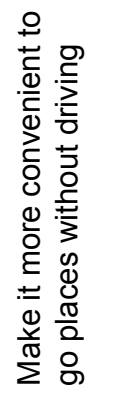 & 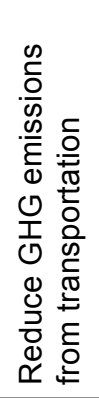 \\
\hline \multicolumn{7}{|l|}{ Gender } \\
\hline Male & 99 & 97 & 97 & 92 & 90 & 87 \\
\hline Female & $97^{\star *}$ & 97 & 98 & $95^{\star \star}$ & $92^{*}$ & $92^{* *}$ \\
\hline \multicolumn{7}{|l|}{ Of Hispanic/Latino origin/descent } \\
\hline Yes & 98 & 98 & 97 & 94 & 92 & 92 \\
\hline No & 98 & 97 & 97 & 93 & $90^{*}$ & $88^{* *}$ \\
\hline \multicolumn{7}{|l|}{ Race } \\
\hline White only & 98 & 97 & 97 & 92 & 89 & 88 \\
\hline Black/African-American only & $95^{\star *}$ & 96 & 95 & 95 & $98^{* \star}$ & 89 \\
\hline Asian/Asian-American only & 99 & 98 & 97 & $96^{* *}$ & $95^{\star \star}$ & $96^{* *}$ \\
\hline Other, including multiracial & 99 & 98 & $96^{*}$ & 91 & $93^{*}$ & $92^{* *}$ \\
\hline \multicolumn{7}{|l|}{ Education } \\
\hline High school or less & 96 & 95 & 96 & 92 & 90 & 88 \\
\hline Some college & $99^{* *}$ & $97^{* *}$ & $98^{*}$ & $94^{*}$ & $92^{*}$ & 91 \\
\hline College graduate & $99^{* *}$ & $99^{* *}$ & $98^{* *}$ & $94^{*}$ & 91 & 91 \\
\hline \multicolumn{7}{|l|}{ Employment status } \\
\hline Working for pay & 98 & 97 & 98 & 94 & 93 & 90 \\
\hline Unemployed but looking for work & 97 & 97 & $95^{* *}$ & 93 & $96^{*}$ & 93 \\
\hline Not working for pay, by choice (retired, etc.) & 98 & 96 & $96^{*}$ & $92^{* *}$ & $86^{* \star}$ & $88^{*}$ \\
\hline \multicolumn{7}{|l|}{ Income (annual household) } \\
\hline$\$ 0-\$ 49,999$ & 97 & 97 & 97 & 93 & 92 & 89 \\
\hline$\$ 50,000-\$ 99,999$ & $99^{* *}$ & 97 & 98 & 94 & $89^{*}$ & 90 \\
\hline$\$ 100,000-\$ 149,999$ & $100^{* *}$ & $99^{*}$ & $99^{*}$ & $97^{* *}$ & 93 & $94^{* *}$ \\
\hline$\$ 150,000$ or more & $99^{* *}$ & 97 & 96 & 91 & $88^{* \star}$ & 89 \\
\hline \multicolumn{7}{|l|}{ Age (years) } \\
\hline $18-24$ & 96 & 95 & 96 & 93 & 91 & 91 \\
\hline $25-44$ & 97 & $97^{* *}$ & 97 & 93 & 92 & 90 \\
\hline $45-64$ & $99^{\star *}$ & $98^{* *}$ & 97 & 94 & 91 & 90 \\
\hline $65+$ & $100^{* *}$ & $98^{* *}$ & $99^{* *}$ & 91 & $86^{\star \star}$ & $87^{*}$ \\
\hline
\end{tabular}




\section{Table 17. Percent of Respondents Rating Transportation-Related Goals for California as Important ${ }^{a}$, by Geography}

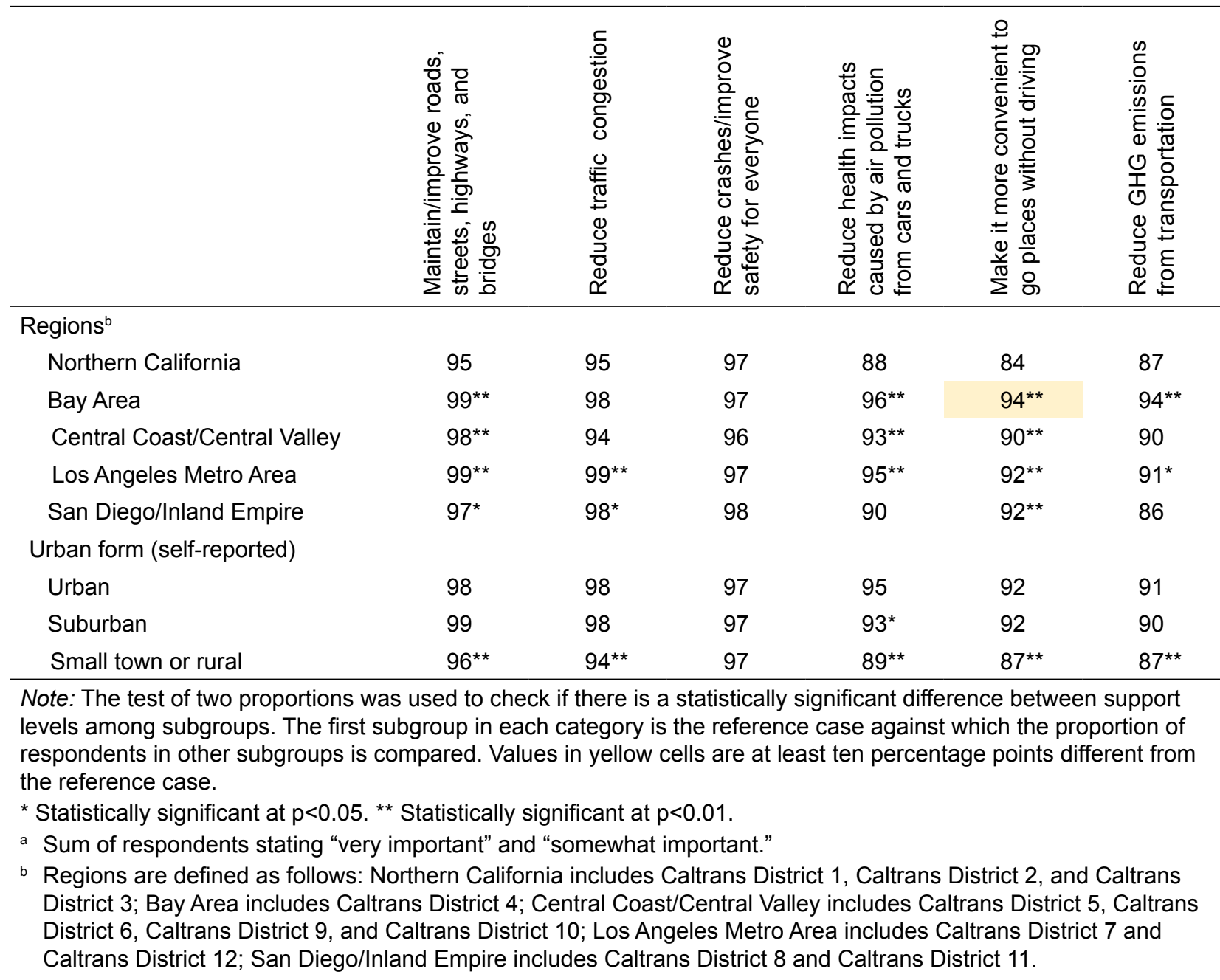




\section{Table 18. Percent of Respondents Rating Transportation-Related Goals for California as Important ${ }^{a}$, by Political Affiliation}

\begin{tabular}{|c|c|c|c|c|c|c|}
\hline & 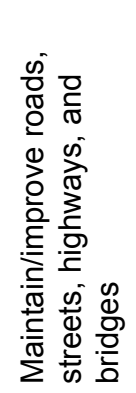 & 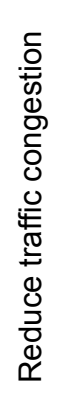 & 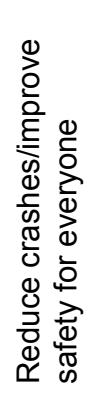 & 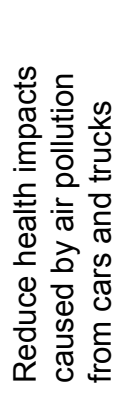 & 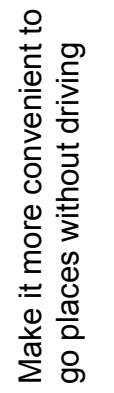 & 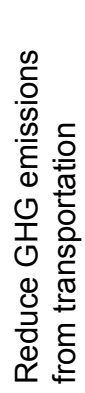 \\
\hline Republican/lean Republican ${ }^{b}$ & 99 & 96 & 95 & 89 & 85 & 80 \\
\hline Democrat/lean Democratic ${ }^{c}$ & $98^{* *}$ & $99^{* *}$ & $98^{* *}$ & $96^{* *}$ & $97^{* * e}$ & $96^{* *}$ \\
\hline Some other party ${ }^{d}$ & $96^{* *}$ & 96 & 97 & 92 & 86 & $89^{* *}$ \\
\hline Independent, no party affiliation & 99 & $90 * *$ & 97 & $96^{* *}$ & 90 & $94^{* *}$ \\
\hline
\end{tabular}

Note: The test of two proportions was used to check if there is a statistically significant difference between support levels among subgroups. The first subgroup in each category is the reference case against which the proportion of respondents in other subgroups is compared. Values in yellow cells are at least ten percentage points different from the reference case.

* Statistically significant at $p<0.05 .{ }^{* *}$ Statistically significant at $p<0.01$.

a Sum of respondents stating "very important" and "somewhat important."

b Respondents who considered themselves a Republican or "lean" towards the Republican Party.

c Includes respondents who considered themselves a Democrat or "lean" towards the Democratic Party.

d Respondents who considered themselves some other party (not Republican, Democratic, or independent).

e Notably different from "some other party" at $p<0.01$. 
Table 19. Percent of Respondents Rating Transportation-Related Goals for California as Important ${ }^{a}$, by Travel Behavior

\begin{tabular}{|c|c|c|c|c|c|c|}
\hline & 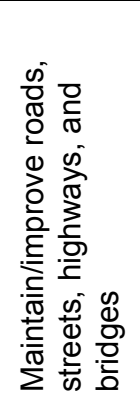 & 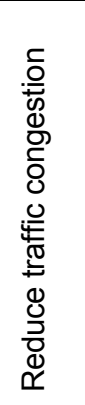 & 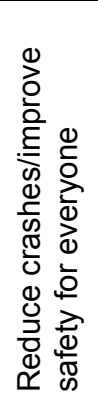 & 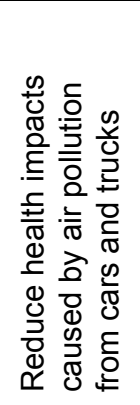 & 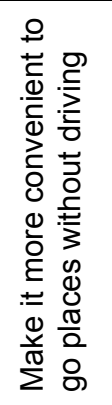 & 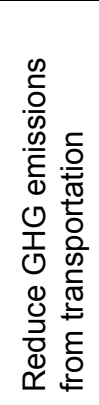 \\
\hline \multicolumn{7}{|l|}{ Transit use } \\
\hline Used in last 30 days & 97 & 97 & 95 & 95 & 94 & 94 \\
\hline Not used in last 30 days & 98 & 98 & $98^{\star *}$ & $92^{* *}$ & $89^{* *}$ & $89^{* *}$ \\
\hline \multicolumn{7}{|l|}{ Walk } \\
\hline Used in last 30 days & 98 & 97 & 97 & 94 & 92 & 92 \\
\hline Not used in last 30 days & 98 & 98 & 97 & $92^{*}$ & $88^{\star *}$ & $88^{* *}$ \\
\hline \multicolumn{7}{|l|}{ Bicycle } \\
\hline Used in last 30 days & 97 & 97 & 95 & 93 & 92 & 92 \\
\hline Not used in last 30 days & $98^{*}$ & 97 & $98^{* *}$ & 93 & 90 & 90 \\
\hline \multicolumn{7}{|l|}{ Ridehail (i.e. Uber/Lyft) } \\
\hline Used in last 30 days & 99 & 98 & 97 & 96 & 94 & 94 \\
\hline Not used in last 30 days & $97^{* *}$ & 97 & 97 & $92^{* *}$ & $89^{* *}$ & $89^{* *}$ \\
\hline \multicolumn{7}{|c|}{ Electric kick-scooter, skateboard, etc. } \\
\hline Used in last 30 days & 96 & 94 & 92 & 91 & 93 & 93 \\
\hline Not used in last 30 days & $98^{* *}$ & $98^{* *}$ & $98^{* *}$ & $94^{*}$ & 90 & 90 \\
\hline \multicolumn{7}{|l|}{ Annual miles driven } \\
\hline $1-3,000$ & 98 & 98 & 99 & 93 & 93 & 93 \\
\hline $3,001-9,000$ & $99^{*}$ & 98 & 98 & 93 & $90^{*}$ & $90^{*}$ \\
\hline $9,001-13,000$ & 98 & $99^{*}$ & 98 & 95 & 90 & 90 \\
\hline $13,001+$ & 99 & 96 & $96^{* *}$ & 92 & $89^{*}$ & $89^{*}$ \\
\hline Don't drive & $96^{\star *}$ & $94^{* *}$ & $93^{* *}$ & 93 & 91 & 91 \\
\hline \multicolumn{7}{|l|}{ Miles per gallona } \\
\hline$\leq 16$ & 97 & 95 & 98 & 89 & 90 & 90 \\
\hline $17-21$ & $99^{*}$ & $98^{*}$ & 98 & 88 & 89 & 89 \\
\hline $22-28$ & $99^{*}$ & $98^{* *}$ & 98 & $94^{* *}$ & 90 & 90 \\
\hline $29-43$ & 98 & $99^{* *}$ & 98 & $93^{*}$ & 91 & 91 \\
\hline $44+$ (or EV) & 98 & $98^{*}$ & 96 & $98^{* * \mathrm{~b}}$ & 89 & 89 \\
\hline Don't know & $99^{* \star}$ & $98^{* *}$ & 98 & $97^{* *}$ & $95^{\star *}$ & $95^{* *}$ \\
\hline
\end{tabular}

Note: The test of two proportions was used to check if there is a statistically significant difference between support levels among subgroups. The first subgroup in each category is the reference case against which the proportion of respondents in other subgroups is compared.

${ }^{*}$ Statistically significant at $p<0.05 .{ }^{* *}$ Statistically significant at $p<0.01$.

a Sum of respondents stating "very important" and "somewhat important."

b Statistically significant difference $(p<0.01)$ of at least ten percentage points from respondents with vehicles getting 17 to 21 miles per gallon. 


\section{PRIORITY RATING FOR SPENDING OPTIONS}

In addition to asking respondents about their broad goals for improving the transportation system, the survey listed 13 different ways the state could spend the money collected through SB1 taxes and asked respondents what priority they would place on each. All options were quite popular; at least two-thirds of respondents rating each option as a medium or high priority. The two options with the largest percent of respondents rating them a medium or high priority were maintaining interstates, highways, and freeways (94\%) and maintaining local streets and roads (93\%). The least popular options related to encouraging people to buy electric vehicles, but even these were rated positively by at least $63 \%$ of respondents.

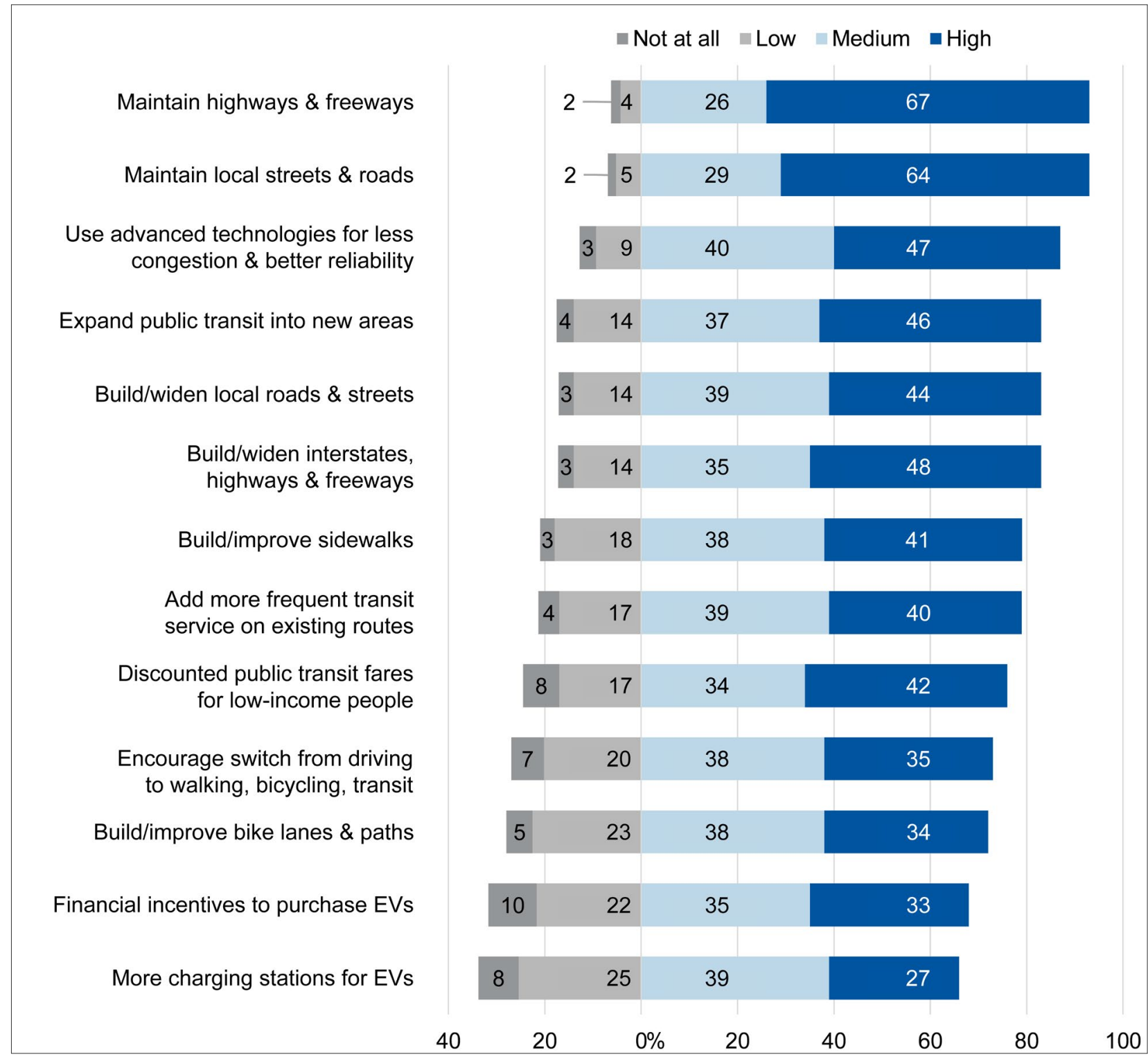

Figure 4. Priority Placed on Different Options for Spending SB1 Revenue 
Tables 20 through 24 present an analysis of how different subgroups rated the 13 spending options. Several cross-cutting patterns stand out with respect to sub-groups that met our criteria for meaningful variation, a statistically significant difference of at least ten percentage points:

- Respondents' satisfaction with both transportation infrastructure and the agencies managing them was strongly correlated with the priority they put on all the options. Respondents who rated any of these as "somewhat good" or "very good" were more likely to support almost all the different spending options.

- There were very few differences among subgroups in the priority placed on any of the options related to local streets and highways. The only variations were linked to the assessment of transportation infrastructure and transportation agencies.

- The youngest respondents (18 to 24 years old) were more supportive than the oldest respondents ( 65 years and older) of virtually all the options related to public transit, active transportation, and electric vehicles.

- Democrat-leaning respondents were more supportive than Republican-learning respondents of all the options related to public transit, active transportation, and electric vehicles. People who leaned towards parties other than the Democratic or Republican parties, or were party-independent, were also more supportive than Republicans of many of the options.

- The majority of respondents in every subgroup, even subgroups comparatively less supportive of an option, rated each option as at least "somewhat" of a priority. 
Table 20. Percent of Respondents Identifying Spending Priorities as Important ${ }^{\mathrm{a}}$, by Socio-Demographic Characteristics

\begin{tabular}{|c|c|c|c|c|c|c|c|c|c|c|c|c|c|c|}
\hline & & 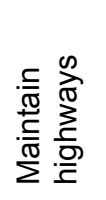 & 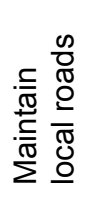 & 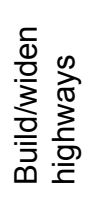 & 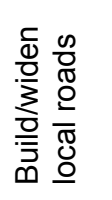 & 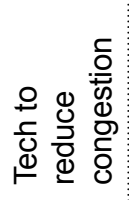 & 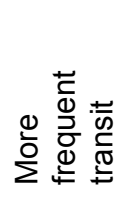 & 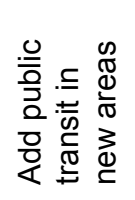 & 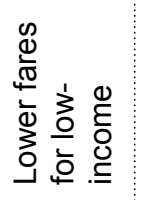 & $\begin{array}{l}\frac{\infty}{1} \\
\frac{1}{\pi} \\
\frac{0}{0} \\
\frac{0}{0}\end{array}$ & 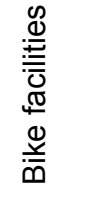 & $\begin{array}{l}\frac{\infty}{0} \\
\frac{2}{0} \\
\frac{0}{0} \\
\frac{c}{0} \\
⿱ 亠 䒑\end{array}$ & 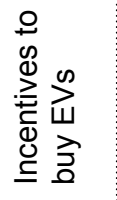 & 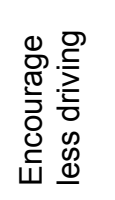 \\
\hline \multirow[t]{2}{*}{ Gender } & Male & 94 & 93 & 84 & 84 & 88 & 77 & 81 & 73 & 74 & 69 & 68 & 69 & 73 \\
\hline & Female & 93 & 93 & 81 & $81^{*}$ & 86 & 80 & $84^{*}$ & $79^{* *}$ & $84^{* *}$ & $75^{\star *}$ & $64^{*}$ & 67 & 74 \\
\hline \multirow[t]{2}{*}{$\begin{array}{l}\text { Hispanic/ } \\
\text { Latino }\end{array}$} & Yes & 93 & 92 & 82 & 85 & 87 & 82 & 87 & 84 & 84 & 77 & 70 & 73 & 76 \\
\hline & No & 94 & $94^{*}$ & 83 & $81^{* *}$ & 88 & $76^{\star *}$ & $80^{* *}$ & $70^{* *}$ & $75^{\star *}$ & $69^{* *}$ & $64^{* *}$ & $65^{\star *}$ & $71^{* *}$ \\
\hline \multirow[t]{4}{*}{ Race } & White only & 94 & 94 & 83 & 82 & 87 & 77 & 81 & 73 & 79 & 70 & 64 & 66 & 72 \\
\hline & $\begin{array}{l}\text { Black/African-American } \\
\text { only }\end{array}$ & 94 & $90^{*}$ & $73^{* *}$ & 81 & 88 & 79 & $92^{* *}$ & $82^{* *}$ & $73^{*}$ & $76^{*}$ & 69 & 72 & 73 \\
\hline & $\begin{array}{l}\text { Asian/Asian-American } \\
\text { only }\end{array}$ & 95 & 93 & 87 & 85 & $92^{*}$ & $84^{* *}$ & 84 & 74 & 80 & 74 & $70^{*}$ & $74^{* *}$ & $83^{* * b}$ \\
\hline & $\begin{array}{l}\text { Other, including } \\
\text { multiracial }\end{array}$ & 93 & $87^{* *}$ & $79^{*}$ & 83 & 85 & 78 & $89^{* *}$ & $80^{* *}$ & 78 & 73 & $71^{* *}$ & $72^{*}$ & 71 \\
\hline \multirow[t]{3}{*}{ Education } & High school or less & 90 & 90 & 79 & 86 & 84 & 79 & 85 & 81 & 82 & 76 & 68 & 71 & 73 \\
\hline & Some college & $96^{* *}$ & $95^{* *}$ & $85^{\star *}$ & 83 & $88^{* *}$ & 78 & 82 & $77^{*}$ & 80 & $72^{*}$ & 66 & $67^{*}$ & 72 \\
\hline & College graduate & $97^{* *}$ & $95^{\star *}$ & $84^{* *}$ & $79^{* *}$ & $90^{* *}$ & 78 & $81^{*}$ & $68^{* *}$ & $74^{* *}$ & $67^{* *}$ & 64 & $66^{*}$ & 74 \\
\hline \multirow[t]{3}{*}{ Employment } & Working for pay & 93 & 93 & 85 & 85 & 88 & 81 & 84 & 77 & 82 & 74 & 67 & 71 & 77 \\
\hline & Unemployed but looking & 96 & 90 & $70^{\star \star \mathrm{h}}$ & 84 & 90 & 82 & $92^{* * \mathrm{e}}$ & $86^{* *}$ e & 80 & $81^{* \mathrm{e}}$ & $76^{* * \mathrm{e}}$ & 76 & 74 \\
\hline & Not working by choice & 94 & 94 & $81^{* *}$ & $79^{* *}$ & $84^{* *}$ & $73^{* *}$ & $78^{* *}$ & $71^{* *}$ & $74^{* *}$ & $66^{* *}$ & $63^{*}$ & $61^{* * c}$ & $66^{* *}$ \\
\hline \multirow{4}{*}{$\begin{array}{l}\text { Income } \\
\text { (annual } \\
\text { household) }\end{array}$} & $\$ 0-\$ 49,999$ & 92 & 92 & 79 & 82 & 85 & 79 & 85 & 82 & 82 & 77 & 67 & 70 & 74 \\
\hline & $\$ 50,000-\$ 99,999$ & $95^{\star *}$ & $94^{*}$ & $86^{\star *}$ & 83 & $88^{*}$ & 78 & $80^{* *}$ & $71^{* *}$ & $78^{*}$ & $67^{\star *}$ & 65 & 67 & 73 \\
\hline & $\$ 100,000-\$ 149,999$ & $98^{* *}$ & $97^{* *}$ & $88^{* *}$ & 83 & $93^{* *}$ & 82 & 82 & $73^{* * f}$ & $82^{f}$ & $71^{*}$ & 70 & 71 & 76 \\
\hline & $\$ 150,000$ or more & 93 & 93 & $87^{* *}$ & 84 & $90^{* *}$ & 76 & $79^{* *}$ & $60^{* * \mathrm{~b}}$ & $68^{* * b}$ & $63^{* *}$ & $61^{*}$ & $63^{* *}$ & $68^{*}$ \\
\hline
\end{tabular}




\section{Table 20, continued}

\begin{tabular}{|c|c|c|c|c|c|c|c|c|c|c|c|c|c|c|}
\hline & & 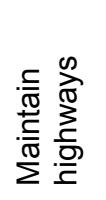 & 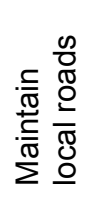 & 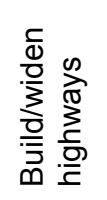 & 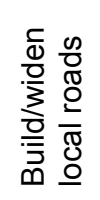 & 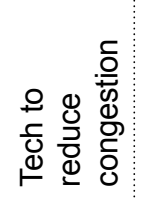 & 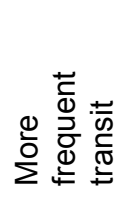 & 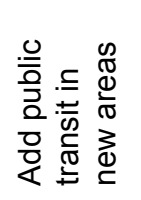 & 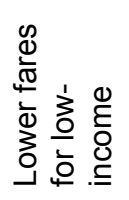 & $\begin{array}{l}\frac{\infty}{y} \\
\bar{\pi} \\
\sum_{0}^{0} \\
\frac{0}{\infty}\end{array}$ & 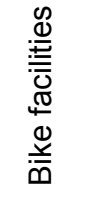 & $\begin{array}{l}\frac{0}{0} \\
\frac{0}{0} \\
\frac{c}{0} \\
> \\
\text { ய }\end{array}$ & 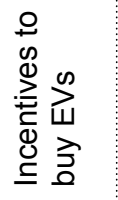 & 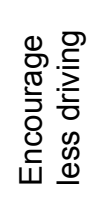 \\
\hline \multirow[t]{4}{*}{ Age (years) } & $18-24$ & 90 & 92 & 75 & 84 & 86 & 79 & 88 & 82 & 80 & 78 & 73 & 76 & 75 \\
\hline & $25-44$ & 92 & $89^{*}$ & $83^{* *}$ & 84 & 87 & 80 & $84^{* *}$ & 80 & 83 & 76 & $67^{* *}$ & 72 & 77 \\
\hline & $45-64$ & $96^{\star *}$ & $96^{* *}$ & $88^{* *}$ & 84 & 87 & 81 & $83^{* *}$ & $73^{* *}$ & 80 & $70^{\star *}$ & $65^{\star *}$ & $65^{\star *}$ & $70^{*}$ \\
\hline & $65+$ & $98^{* *}$ & $98^{* *}$ & $84^{* *}$ & $78^{*}$ & 89 & $\begin{array}{l}71^{* *} \\
\end{array}$ & $74^{* * d}$ & $64^{* * d}$ & $69^{* * b}$ & $60^{* * b}$ & $60^{* *}$ & $56^{* * d}$ & $67^{* * d}$ \\
\hline
\end{tabular}

Note: The test of two proportions was used to check if there is a statistically significant difference between support levels among subgroups. The first subgroup in each category is the reference case against which the proportion of respondents in other subgroups is compared. Values in yellow cells are at least ten percentage points different from the reference case.

* Statistically significant at $p<0.05$. ${ }^{* *}$ Statistically significant at $p<0.01$.

a Sum of respondents stating "very important" and "somewhat important."

b A statistically significant difference $(p<.01)$ of at least ten percentage points from respondents in all other subgroups.

c A statistically significant difference $(p<.01)$ of at least ten percentage points from unemployed respondents.

d A statistically significant difference $(p<.01)$ of at least ten percentage points from respondents $22-44$ years old.

e A statistically significant difference $(p<.01)$ of at least ten percentage points from respondents not working by choice.

$f$ A statistically significant difference $(p<.01)$ of at least ten percentage points from respondents with household incomes of $\$ 150,000$ or more.

$g$ A statistically significant difference $(p<.01)$ of at least ten percentage points from $45-64$ years old.

h A statistically significant difference $(p<.01)$ of at least ten percentage points from respondents not working by choice. 
Table 21. Percent of Respondents Identifying Spending Priorities as Important ${ }^{a}$, by Travel Behavior

\begin{tabular}{|c|c|c|c|c|c|c|c|c|c|c|c|c|c|}
\hline & 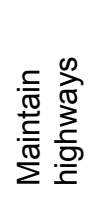 & 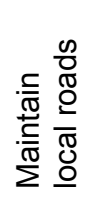 & 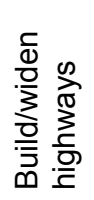 & 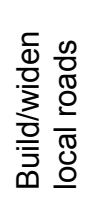 & 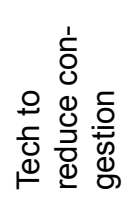 & 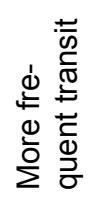 & 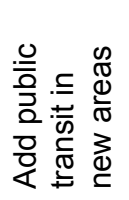 & 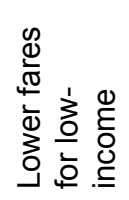 & $\begin{array}{l}\frac{\infty}{10} \\
\frac{\pi}{0} \\
\frac{d}{0} \\
\frac{0}{\infty}\end{array}$ & 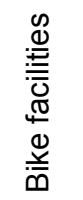 & $\begin{array}{l}\frac{0}{0} \\
\frac{0}{0} \\
\frac{0}{0} \\
\frac{1}{0} \\
\frac{>}{4}\end{array}$ & 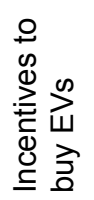 & 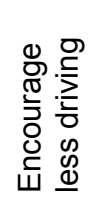 \\
\hline \multicolumn{14}{|l|}{ Public transit } \\
\hline Used in last 30 days & 93 & 92 & 81 & 84 & 89 & 86 & 88 & 83 & 82 & 80 & 73 & 75 & 79 \\
\hline Not used in last 30 days & 94 & $94^{*}$ & $84^{*}$ & 82 & $86^{*}$ & $74^{* *}$ & $79^{* *}$ & $71^{* *}$ & $77^{* *}$ & $67^{* *}$ & $62^{* *}$ & $64^{* *}$ & $69^{* *}$ \\
\hline \multicolumn{14}{|l|}{ Walk } \\
\hline Used in last 30 days & 93 & 92 & 82 & 82 & 88 & 81 & 85 & 79 & 81 & 75 & 68 & 70 & 76 \\
\hline Not used in last 30 days & $96^{* *}$ & $96^{* *}$ & $86^{* *}$ & 84 & 86 & $71^{* *}$ & $77^{* *}$ & $68^{* *}$ & $75^{* *}$ & $63^{* *}$ & $63^{* *}$ & $63^{* *}$ & $66^{* *}$ \\
\hline \multicolumn{14}{|l|}{ Bicycle } \\
\hline Used in last 30 days & 90 & 88 & 79 & 85 & 85 & 80 & 87 & 80 & 78 & 83 & 74 & 76 & 78 \\
\hline Not used in last 30 days & $95^{\star *}$ & $95^{* *}$ & $84^{* *}$ & $82^{\star *}$ & $88^{*}$ & 78 & $81^{* *}$ & $74^{* *}$ & 80 & $68^{* *}$ & $63^{* *}$ & $65^{\star *}$ & $71^{* *}$ \\
\hline \multicolumn{14}{|l|}{ Ridehail } \\
\hline Used in last 30 days & 93 & 92 & 86 & 86 & 90 & 83 & 88 & 79 & 83 & 79 & 71 & 76 & 76 \\
\hline Not used in last 30 days & 94 & 93 & $81^{* *}$ & $81^{* *}$ & $86^{\star *}$ & $76^{* *}$ & $79^{* *}$ & $74^{* *}$ & $77^{* *}$ & $67^{* *}$ & $63^{* *}$ & $64^{\star *}$ & $71^{* *}$ \\
\hline \multicolumn{14}{|l|}{$\begin{array}{l}\text { E-scooter, skateboard, } \\
\text { etc. }\end{array}$} \\
\hline Used in last 30 days & 84 & 86 & 76 & 87 & 82 & 78 & 85 & 77 & 74 & 79 & 75 & 74 & 76 \\
\hline Not used in last 30 days & $96^{* *}$ & $94^{* *}$ & $84^{\star *}$ & $82^{* *}$ & $88^{* *}$ & 79 & 83 & 76 & $80^{* *}$ & $71^{* *}$ & $65^{\star \star}$ & $67^{\star \star}$ & 73 \\
\hline \multicolumn{14}{|l|}{ Annual miles driven } \\
\hline $1-3,000$ & 93 & 92 & 79 & 80 & 86 & 81 & 84 & 81 & 80 & 74 & 69 & 70 & 71 \\
\hline $3,001-9,000$ & $98^{* *}$ & $96^{* *}$ & $84^{*}$ & 80 & $90^{* *}$ & $75^{\star *}$ & $78^{* *}$ & $70^{\star *}$ & $75^{*}$ & $64^{* *}$ & $63^{*}$ & $64^{*}$ & 70 \\
\hline $9,001-13,000$ & $96^{*}$ & 94 & $87^{* *}$ & $85^{*}$ & 89 & 79 & 84 & $74^{\star *}$ & 81 & $67^{* *}$ & 66 & 68 & 76 \\
\hline $13,001+$ & 93 & 94 & $88^{* *}$ & $86^{* *}$ & 87 & 80 & $79^{*}$ & $72^{* *}$ & 79 & $70^{*}$ & $63^{*}$ & 67 & 75 \\
\hline Don't drive & $89^{* *}$ & $89^{*}$ & 76 & 83 & 84 & 78 & $89^{* *}$ & 81 & 81 & $84^{* *}$ & 69 & 71 & 73 \\
\hline
\end{tabular}




\section{Table 21, continued}

\begin{tabular}{|c|c|c|c|c|c|c|c|c|c|c|c|c|c|}
\hline & 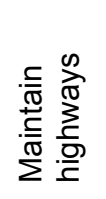 & 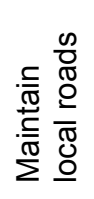 & $\begin{array}{l}\frac{c}{0} \\
\frac{0}{0} \frac{n}{3} \\
\frac{0}{3} \\
\frac{0}{3} \\
\frac{1}{n} \\
\frac{0}{c}\end{array}$ & 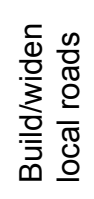 & 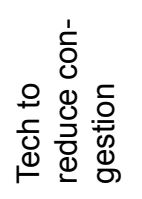 & 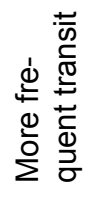 & 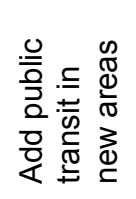 & 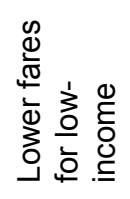 & $\begin{array}{l}\frac{\infty}{y} \\
\frac{1}{N 0} \\
\frac{0}{0} \\
\frac{0}{0}\end{array}$ & 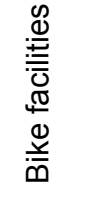 & $\begin{array}{l}\frac{\infty}{0} \\
\frac{0}{0} \\
\frac{0}{0} \\
\frac{c}{0} \\
\text { य }\end{array}$ & 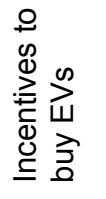 & 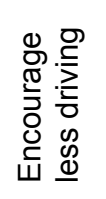 \\
\hline \multicolumn{14}{|l|}{ Miles per gallon } \\
\hline$\leq 16$ & 89 & 94 & 85 & 82 & 89 & 79 & 83 & 81 & 80 & 70 & 60 & 67 & 69 \\
\hline $17-21$ & $98^{* *}$ & 95 & 88 & 82 & 85 & $70^{* *}$ & $74^{\star *}$ & $65^{\star *}$ & $72^{*}$ & 64 & 63 & $58^{* *}$ & 67 \\
\hline $22-28$ & $98^{* *}$ & $97^{*}$ & 83 & 81 & 89 & 77 & 79 & $69^{* *}$ & 75 & 66 & 63 & 65 & 70 \\
\hline $29-43$ & $96^{* *}$ & 94 & 84 & 82 & 89 & 79 & 82 & $73^{*}$ & 81 & 67 & 63 & 66 & $76^{*}$ \\
\hline 44+ (incl. EV) & 89 & $87^{* *}$ & 83 & $88^{*}$ & 87 & $91^{* *}$ & 88 & $87^{* \mathrm{~b}}$ & 83 & $82^{* * b}$ & $85^{* * b}$ & $84^{\star * b}$ & $89^{* * \mathrm{~b}}$ \\
\hline Don't know & $94^{* *}$ & 93 & 82 & 83 & 88 & 83 & 86 & 80 & 82 & 72 & $68^{*}$ & 71 & 74 \\
\hline
\end{tabular}

Note: The test of two proportions was used to check if there is a statistically significant difference between support levels among subgroups. The first subgroup in each category is the reference case against which the proportion of respondents in other subgroups is compared. Values in yellow cells are at least ten percentage points different from the reference case.

* Statistically significant at $p<0.05 .{ }^{* *}$ Statistically significant at $p<0.01$.

a Sum of respondents stating "very important" and "somewhat important."

b The difference between this group and all other mileage sub-groups except "Don't know" is at least ten percentage points and statistically significant at p<0.05 
Table 22. Percent of Respondents Identifying Spending Priorities as Important ${ }^{\text {a }}$, by Geography

\begin{tabular}{|c|c|c|c|c|c|c|c|c|c|c|c|c|c|}
\hline & 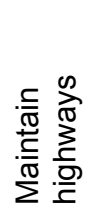 & 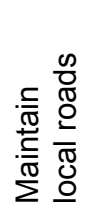 & 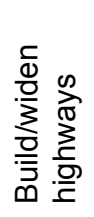 & 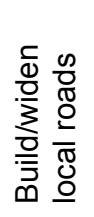 & 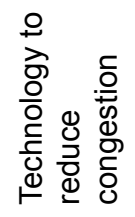 & 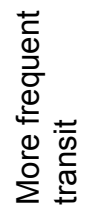 & 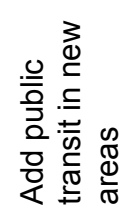 & 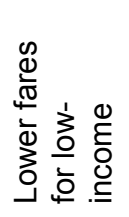 & $\begin{array}{l}\frac{\infty}{1} \\
\frac{\sqrt{N}}{3} \\
\frac{0}{0} \\
\frac{0}{0}\end{array}$ & 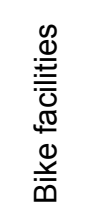 & $\begin{array}{l}\frac{\infty}{0} \\
\frac{0}{0} \\
\frac{1}{0} \\
\frac{c}{0} \\
\frac{>}{山}\end{array}$ & 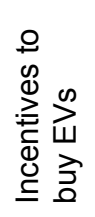 & 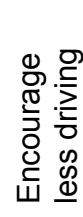 \\
\hline \multicolumn{14}{|l|}{ Region $^{b}$} \\
\hline Northern CA & 89 & 92 & 78 & 82 & 80 & 74 & 79 & 74 & 77 & 69 & 57 & 64 & 72 \\
\hline Bay Area & 90 & 91 & 82 & 82 & 84 & 78 & 83 & 75 & 79 & $76^{* *}$ & $64^{*}$ & 67 & 70 \\
\hline Central Coast/Central Valley & $97^{\star \star}$ & $95^{*}$ & 83 & 82 & $91^{* *}$ & $81^{* *}$ & 84 & 74 & 77 & 69 & $65^{* *}$ & 68 & 76 \\
\hline LA Metro Area & $96^{* *}$ & 93 & $83^{*}$ & 85 & $89^{* *}$ & $83^{* *}$ & $85^{* *}$ & 78 & $83^{*}$ & $75^{* *}$ & $71^{* *}$ & $73^{* *}$ & $77^{*}$ \\
\hline San Diego/Inland Empire & $95^{* *}$ & 94 & $85^{* *}$ & 81 & $89^{* *}$ & 74 & 80 & 76 & 77 & 68 & $67^{* *}$ & 64 & 68 \\
\hline \multicolumn{14}{|l|}{ Urban form (self-reported) } \\
\hline Urban & 93 & 93 & 83 & 86 & 88 & 85 & 87 & 81 & 85 & 79 & 72 & 74 & 78 \\
\hline Suburban & $95^{\star *}$ & $95^{*}$ & 84 & $80^{* *}$ & 89 & $76^{\star *}$ & $81^{* *}$ & $72^{* *}$ & $74^{* *}$ & $67^{* *}$ & $64^{* *}$ & $66^{* *}$ & $70^{* *}$ \\
\hline Small town or rural & 92 & $90^{*}$ & $79^{*}$ & $81^{* *}$ & $82^{* *}$ & $74^{* *}$ & $80^{* *}$ & $76^{* *}$ & $80^{* *}$ & $70^{* *}$ & $61^{* *}$ & $63^{* *}$ & $71^{* *}$ \\
\hline
\end{tabular}

Note: The test of two proportions was used to check if there is a statistically significant difference between support levels among subgroups. The first subgroup in each category is the reference case against which the proportion of respondents in other subgroups is compared. Values in yellow cells are at least ten percentage points different from the reference case.

* Statistically significant at $p<0.05 .{ }^{* *}$ Statistically significant at $p<0.01$.

a Sum of respondents stating "very important" and "somewhat important."

b Regions are defined as follows: Northern California includes Caltrans District 1, Caltrans District 2, and Caltrans District 3; Bay Area includes Caltrans District 4; Central Coast/Central Valley includes Caltrans District 5, Caltrans District 6, Caltrans District 9, and Caltrans District 10; Los Angeles Metro Area includes Caltrans District 7 and Caltrans District 12; San Diego/Inland Empire includes Caltrans District 8 and Caltrans District 11. 


\section{Table 23. Percent of Respondents Identifying Spending Priorities as Important ${ }^{a}$, by Political Affiliation}

\begin{tabular}{|c|c|c|c|c|c|c|c|c|c|c|c|c|c|}
\hline Political affiliation & 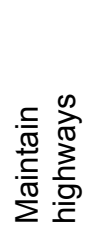 & 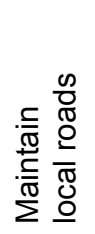 & 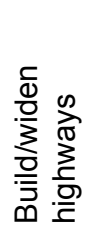 & 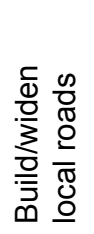 & 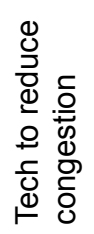 & 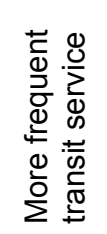 & 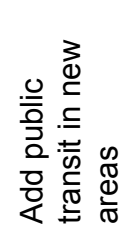 & 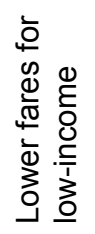 & 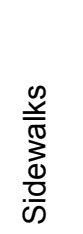 & 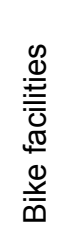 & $\begin{array}{l}\frac{0}{0} \\
\frac{0}{0} \\
\frac{0}{0} \\
\frac{D}{U}\end{array}$ & 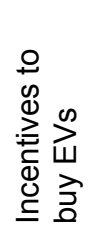 & 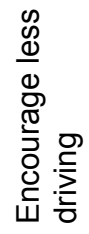 \\
\hline Republican/lean Rep ${ }^{b}$ & 95 & 94 & 85 & 84 & 86 & 70 & 75 & 60 & 69 & 59 & 58 & 58 & 61 \\
\hline Democratic/lean Dem ${ }^{c}$ & 94 & 94 & 82 & 83 & 89 & $85^{* *}$ & $88^{* *}$ & $84^{* *}$ & $82^{* *}$ & $78^{* *}$ & $72^{* *}$ & $74^{* *}$ & $81^{* *}$ \\
\hline Other party $^{d}$ & 93 & $80^{* *}$ & $76^{* *}$ & 86 & $80^{*}$ & 76 & $86^{* *}$ & $78^{* *}$ & $81^{* *}$ & $76^{\star *}$ & $68^{*}$ & $67^{*}$ & $78^{* *}$ \\
\hline Independent, no party affiliation & $90^{* *}$ & 94 & 83 & $80^{*}$ & 87 & $78^{* *}$ & $83^{* *}$ & $80^{* *}$ & $86^{* *}$ & $78^{* *}$ & $64^{* *}$ & $71^{* *}$ & $71^{* *}$ \\
\hline
\end{tabular}

Note: The test of two proportions was used to check if there is a statistically significant difference between support levels among subgroups. The first subgroup in each category is the reference case against which the proportion of respondents in other subgroups is compared. Values in yellow cells are at least ten percentage points different from the reference case.

* Statistically significant at $p<0.05$. ** Statistically significant at $p<0.01$.

a Sum of respondents stating "very important" and "somewhat important."

b Includes respondents who considered themselves a Republican or "lean" towards the Republican Party.

c Includes respondents who considered themselves a Democrat or "lean" towards the Democratic Party.

d Respondents who considered themselves some other party (not Republican, Democrat, or independent). 
Table 24. Percent of Respondents Identifying Spending Priorities as Important ${ }^{\mathrm{a}}$, by Assessment of the Transportation System and Agencies

\begin{tabular}{|c|c|c|c|c|c|c|c|c|c|c|c|c|c|}
\hline Assessment $^{a}$ & 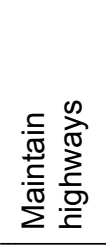 & 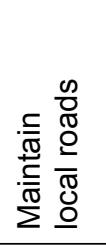 & 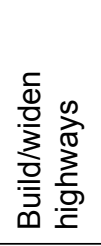 & 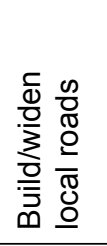 & 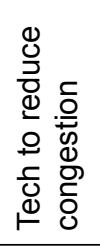 & 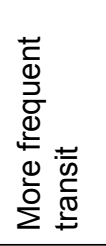 & 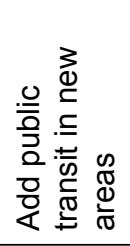 & 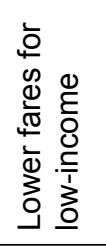 & 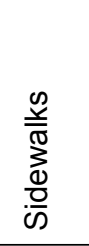 & 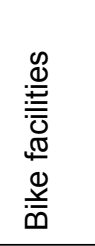 & $\begin{array}{l}\frac{\infty}{d} \\
\frac{D}{D} \\
\frac{0}{0} \\
\frac{0}{山}\end{array}$ & 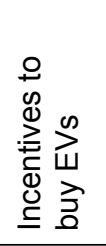 & 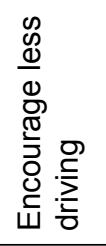 \\
\hline \multicolumn{14}{|c|}{ State highways quality } \\
\hline Good & 95 & 94 & 83 & 84 & 89 & 81 & 85 & 79 & 81 & 75 & 70 & 72 & 76 \\
\hline Bad & 94 & 93 & $86^{*}$ & 82 & $86^{*}$ & $76^{\star \star}$ & $79^{\star *}$ & $70^{* *}$ & $75^{\star *}$ & $66^{\star *}$ & $62^{\star \star}$ & $62^{* *}$ & $69^{* *}$ \\
\hline Don't know & $60^{* *}$ & $61^{* \star}$ & $49^{* *}$ & $71^{* *}$ & $58^{* *}$ & $63^{* *}$ & $76^{*}$ & $66^{* *}$ & $71^{* *}$ & 68 & $34^{\star *}$ & $42^{* *}$ & $55^{\star *}$ \\
\hline \multicolumn{14}{|c|}{ Local roads quality } \\
\hline Good & 95 & 93 & 84 & 84 & 89 & 81 & 84 & 78 & 79 & 76 & 71 & 73 & 76 \\
\hline Bad & $93^{*}$ & $95^{*}$ & 82 & 82 & $86^{*}$ & $77^{* \star}$ & 82 & $73^{* *}$ & 80 & $67^{* \star}$ & $61^{* *}$ & $63^{* *}$ & $70^{* *}$ \\
\hline Don't know & $52^{b}$ & $29^{b}$ & $29^{b}$ & $77^{\mathrm{b}}$ & $48^{b}$ & $39^{b}$ & $78^{b}$ & $55^{b}$ & $47^{\mathrm{b}}$ & $72^{b}$ & $28^{b}$ & $16^{b}$ & $65^{b}$ \\
\hline \multicolumn{14}{|c|}{ Bike/ped infrastructure quality } \\
\hline Good & 96 & 94 & 84 & 84 & 90 & 80 & 84 & 79 & 80 & 73 & 69 & 71 & 75 \\
\hline Bad & $91^{* *}$ & $92^{*}$ & $81^{*}$ & 82 & $86^{* *}$ & 80 & 84 & $75^{\star *}$ & 80 & $76^{*}$ & 66 & $66^{\star *}$ & 75 \\
\hline Don't know & $85^{* *}$ & $87^{* *}$ & $76^{* *}$ & $76^{* *}$ & $74^{* *}$ & $58^{* *}$ & $69^{* *}$ & $56^{* *}$ & $66^{* *}$ & $53^{* *}$ & $45^{\star *}$ & $56^{* *}$ & $53^{* *}$ \\
\hline \multicolumn{14}{|c|}{ Public transit quality } \\
\hline Good & 95 & 94 & 85 & 85 & 89 & 82 & 86 & 81 & 84 & 77 & 70 & 73 & 77 \\
\hline Bad & $91^{* *}$ & 92 & $80^{* *}$ & $79^{* *}$ & $85^{\star *}$ & 79 & $82^{* *}$ & $70^{* *}$ & $75^{* *}$ & $67^{* *}$ & $63^{* *}$ & $62^{* *}$ & $69^{* *}$ \\
\hline Don't know & 94 & 92 & $73^{* *}$ & $80^{*}$ & $80^{* *}$ & $53^{* *}$ & $65^{\star *}$ & $55^{\star *}$ & $62^{* *}$ & $55^{\star *}$ & $47^{* *}$ & $55^{* *}$ & $59^{* *}$ \\
\hline \multicolumn{14}{|c|}{ Concern about congestion } \\
\hline Very & 96 & 94 & 86 & 87 & 92 & 83 & 86 & 78 & 82 & 73 & 68 & 73 & 76 \\
\hline Somewhat & $94^{*}$ & 94 & $81^{* *}$ & $80^{* *}$ & $87^{* *}$ & $78^{* *}$ & $82^{* *}$ & 76 & $79^{*}$ & 73 & 67 & $66^{* *}$ & 73 \\
\hline Not at all & $89^{* *}$ & $91^{*}$ & $79^{* *}$ & $76^{* *}$ & $75^{\star *}$ & $69^{* *}$ & $76^{\star *}$ & $70^{* *}$ & $72^{* *}$ & $66^{* *}$ & $58^{* *}$ & $62^{* *}$ & $61^{* * c}$ \\
\hline \multicolumn{14}{|l|}{ Caltrans } \\
\hline Good job & 95 & 94 & 84 & 83 & 89 & 81 & 85 & 80 & 82 & 76 & 71 & 72 & 76 \\
\hline Bad job & $93^{* *}$ & 93 & 82 & 83 & $86^{*}$ & $75^{\star *}$ & $79^{* *}$ & $67^{* *}$ & $74^{* *}$ & $64^{\star *}$ & $59^{\star *}$ & $62^{* *}$ & $66^{* *}$ \\
\hline Don't know & $82^{* *}$ & $80^{* *}$ & $66^{* *}$ & $75^{* *}$ & $75^{* *}$ & $68^{* *}$ & $75^{* *}$ & $63^{* *}$ & $73^{* *}$ & $63^{* *}$ & $56^{* *}$ & $56^{* *}$ & $68^{* *}$ \\
\hline
\end{tabular}




\section{Table 24, continued}

\begin{tabular}{|c|c|c|c|c|c|c|c|c|c|c|c|c|c|}
\hline Assessment ${ }^{a}$ & 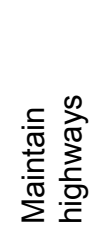 & 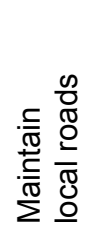 & 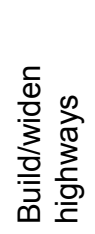 & 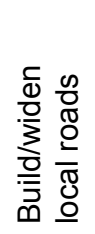 & 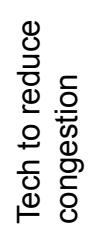 & 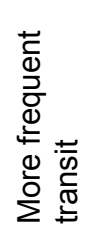 & 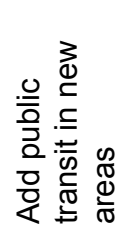 & 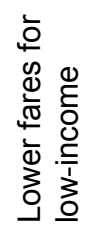 & $\begin{array}{l}\frac{\infty}{10} \\
\frac{\pi}{0} \\
\frac{d}{0} \\
\frac{0}{\omega}\end{array}$ & 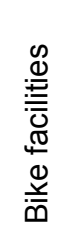 & $\begin{array}{l}\frac{\infty}{0} \\
\frac{0}{0} \\
\frac{D}{0} \\
\frac{c}{0} \\
\frac{1}{W}\end{array}$ & 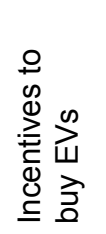 & 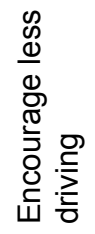 \\
\hline \multicolumn{14}{|c|}{ Transit agencies } \\
\hline Good job & 94 & 94 & 85 & 85 & 90 & 82 & 86 & 82 & 83 & 77 & 71 & 73 & 78 \\
\hline Bad job & 94 & 93 & $80^{* *}$ & $81^{* *}$ & $85^{* *}$ & $75^{* *}$ & $80^{* *}$ & $66^{* *}$ & $73^{* *}$ & $65^{* *}$ & $62^{* *}$ & $62^{* *}$ & $65^{* *}$ \\
\hline Don't know & $82^{* *}$ & $82^{* *}$ & $70^{* *}$ & $69^{* *}$ & $72^{* *}$ & $52^{* *}$ & $61^{* *}$ & $55^{* *}$ & $62^{* *}$ & $49^{* *}$ & $40^{* *}$ & $45^{* *}$ & $57^{* *}$ \\
\hline \multicolumn{14}{|c|}{ Local government } \\
\hline Good job & 94 & 94 & 84 & 84 & 89 & 83 & 87 & 81 & 83 & 79 & 72 & 74 & 78 \\
\hline Bad job & 95 & 94 & $82^{*}$ & $81^{*}$ & $87^{*}$ & $77^{* *}$ & $80^{* *}$ & $71^{* *}$ & $77^{* *}$ & $65^{* *}$ & $61^{* *}$ & $62^{* *}$ & $68^{* *}$ \\
\hline Don't know & $81^{* *}$ & $69^{* *}$ & $68^{* *}$ & $78^{*}$ & $65^{* *}$ & $40^{* *}$ & $59^{* *}$ & $51^{* *}$ & $50^{* *}$ & $54^{* *}$ & $49^{* *}$ & $45^{* *}$ & $60^{* *}$ \\
\hline
\end{tabular}

Note: The test of two proportions was used to check if there is a statistically significant difference between support levels among subgroups. The first subgroup in each category is the reference case against which the proportion of respondents in other subgroups is compared. Values in yellow cells are at least ten percentage points different from the reference case at $p<0.05$.

* Statistically significant at $p<0.05 .{ }^{* *}$ Statistically significant at $p<0.01$.

a Good = "somewhat good" or "very good"; bad = "somewhat bad" or "very bad"; and don't know = "don't know" or "doesn't apply."

b Sample size is too small to conduct statistical testing.

c A statistically significant difference $(p<.01)$ of at least ten percentage points from respondents rating it as "somewhat good." 


\section{TOP SPENDING PRIORITIES}

The survey also asked respondents to select their top three spending priorities from the list. Maintenance, especially for local streets and roads, came out clearly ahead of the other options. Thirty-four percent chose maintaining highways and freeways as a priority, whereas $45 \%$ chose maintaining local streets and roads as a priority.

Looking across the various road-related spending options, it is clear that maintenance was a top priority for more people than was facility expansion, especially for local roads. Only $15 \%$ said building and widening local streets and roads was a top priority, compared to the $45 \%$ who said maintaining them was a top priority.

The various public transit options offered were a top priority for small minorities. The most popular was to subsidize fares for low-income riders $(21 \%)$, followed by expanding service into new areas (19\%), and adding more frequent service on existing routes $(16 \%)$.

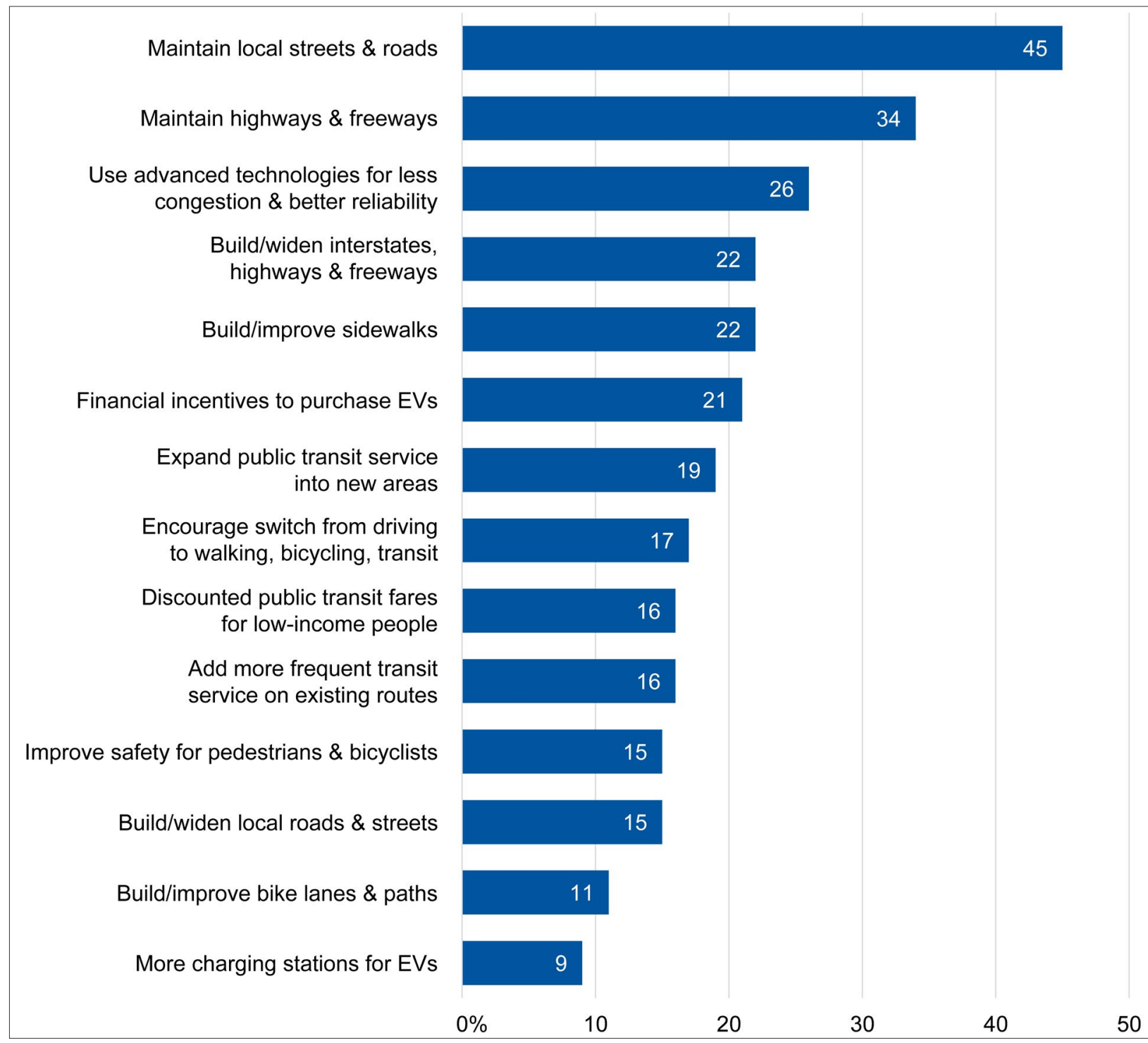

Figure 5. Options Selected as One of the Top Three Priorities for Spending SB1 Revenue 


\section{PREFERRED WAY TO RECEIVE SB1 INFORMATION}

Respondents were asked to what extent they would find "useful" various ways that Caltrans could communicate with the public about how SB1 revenues are spent-with annual DMV registration notices, via monthly emails, via monthly social media, or monthly updates posted on a website. All four options were rated as "somewhat useful" or "very useful" by at least three-quarters of respondents, though monthly social media updates was a modestly less popular option than the other three. Both monthly emails and sharing information in annual DMV vehicle registration notices was rated as "somewhat useful" or "very useful" by $87 \%$, but the latter had slightly higher numbers among those rating it "very useful" (44\% vs. $40 \%) .{ }^{8}$

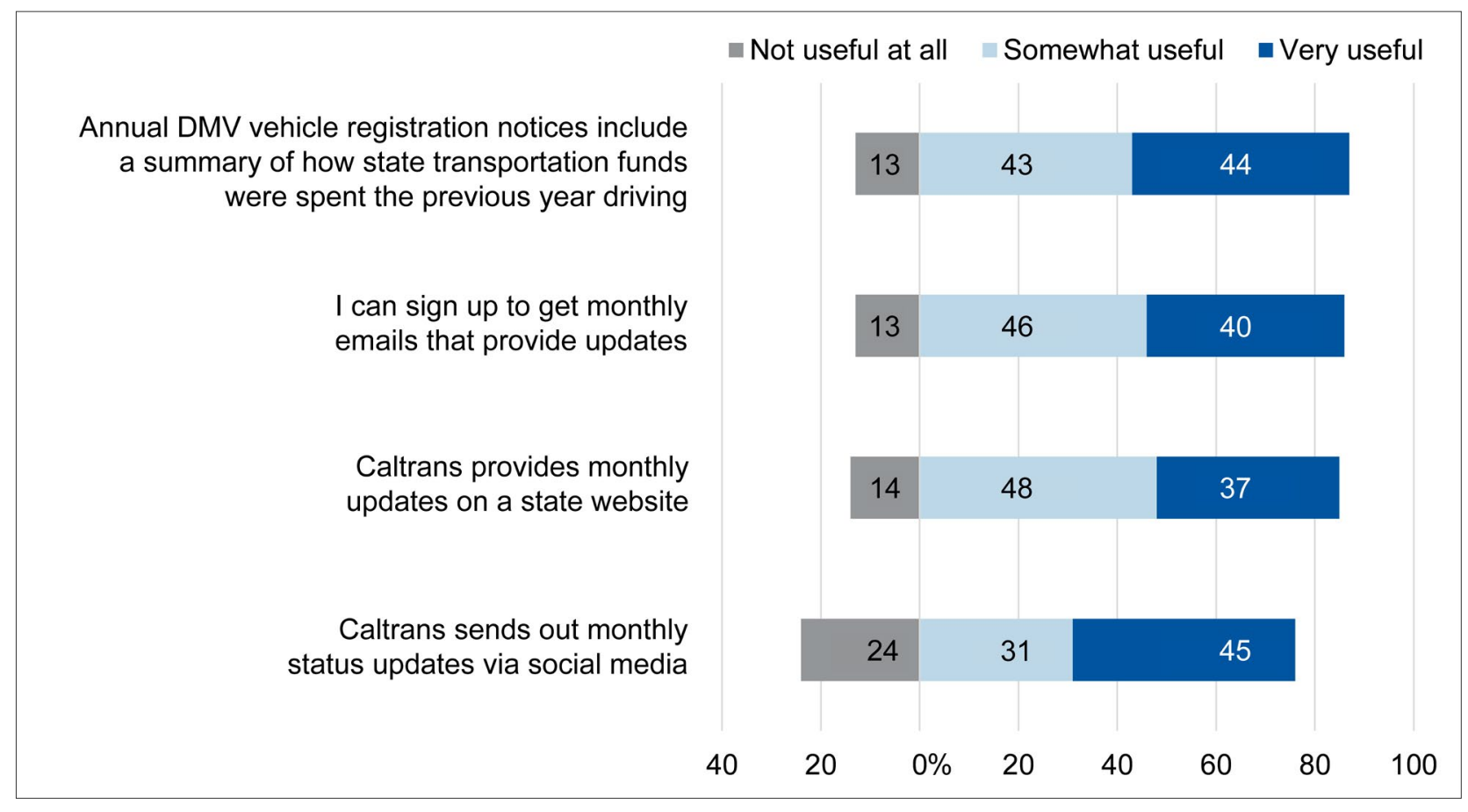

Figure 6. Preferred Way to Receive SB1 Information 


\section{CONCLUSION}

This section concludes the report with a summary of 11 key survey findings about how Californians assessed the state's transportation system, their goals for improvement, and their priorities for how the state invests SB1 revenues. These findings suggest opportunities for state leaders to craft spending programs that directly target the types of improvements the public wishes to see.

\section{RATINGS OF THE TRANSPORTATION SYSTEM AND AGENCIES}

1. The majority of respondents rated all transportation infrastructure and services-local state highways, local streets, public transit, and bicycle/ pedestrian infrastructure-as at least "somewhat good." The percentage was noticeably highest for state highways (68\%) and lowest for local streets and roads $(53 \%)$.

2. Most respondents were at least "somewhat concerned" about traffic congestion. Eighty-six percent of respondents were at least "somewhat concerned" about congestion in their community.

3. The majority of respondents rated the performance of transportation agencies as at least "somewhat good," with the highest approval for Caltrans. These findings mirror those for the assessment of transportation infrastructure and services: the majority of respondents rated all three agency types as either "somewhat good" or "very good," though more respondents approved of Caltrans (65\%) and public transit agencies (64\%) than local city and county governments (54\%).

\section{A VISION FOR IMPROVING THE TRANSPORTATION SYSTEM}

4. Virtually all respondents wanted to see improvements to all modes, reductions in air pollution and greenhouse gas emissions from transportation, and more convenient options to travel without driving. Respondents were asked what priority the state should place on each of six potential goals for improving the transportation system, and at least $90 \%$ of respondents rated each goal as "somewhat important" or "very" important. The three most popular options were maintaining and improving roads, streets, highways, and bridges (98\%), reducing crashes and improving safety for everyone (97\%), and reducing traffic congestion $(97 \%)$.

\section{PREFERENCES FOR HOW CALIFORNIA SPENDS SB1 REVENUE}

5. At least two-thirds of respondents supported every spending option presented. The survey listed 13 different ways the state could spend the money collected through SB1 taxes and asked respondents what priority they would place on each. The options presented covered streets and highways, public transit, active transportation facilities, and electric vehicle incentives. All thirteen options were quite popular, with at least two-thirds rating each one as a medium or high priority. 
6. The public sees highway and local street maintenance as top priorities. The two spending options with the largest percent of respondents rating them a medium or high priority were maintaining interstates, highways, and freeways $(94 \%)$ and maintaining local streets and roads (93\%).

7. Modestly more people prioritized maintenance of local streets and roads than maintenance of highways. The survey asked respondents to select their top three spending priorities from the list of thirteen. Forty-five percent chose maintaining local streets and roads as a priority, compared to $34 \%$ who chose maintaining highways and freeways as a priority.

8. For both highways and local streets, maintenance was a top priority for considerably more people than was expansion. Only $15 \%$ chose building and widening local streets and roads as a top priority, compared to the $45 \%$ who chose maintaining them as a top priority.

9. Most respondents supported transit-related spending improvements, but these were a top priority for only small minorities. The most popular transit option was to subsidize fares for low-income riders $(21 \%)$, followed by expanding service into new areas (19\%), and adding more frequent service on existing routes $(16 \%)$.

10. The least popular spending options related to electric vehicles, though even these options were rated positively by more than two-thirds. For example, $69 \%$ of respondents supported offering subsidies as an incentive to buy electric vehicles.

11. Most respondents would find it "useful" to get information about how SB1 money is spent via monthly emails and/or as inserts in DMV vehicle registration notices. Both options were rated as "somewhat useful" or "very useful" by $87 \%$ of respondents. Slightly fewer respondents, though still a great majority, thought that monthly updates on a Caltrans website would be useful. 


\section{APPENDIX A: SURVEY QUESTIONNAIRE AND TOPLINE RESULTS}

This appendix presents the survey questionnaire and topline results.

The results have been weighted to match the Census Bureau's 2013-2017 American Community Survey five-year estimates with respect to gender, race, Hispanic ethnicity, education level, annual household income, and age for California adults. ${ }^{9}$

The authors removed missing and refused responses from the dataset before calculating the response rates.

Note that some categories in the tables do not sum to $100 \%$ due to rounding.

Researchers at the Mineta Transportation Institute, San Jose State University, are conducting a survey to gather your thoughts about transportation in California. Your opinions are very important, no matter how much or little you travel. Public officials can use the survey results to decide what transportation improvements are most critical throughout the state. The survey takes about 10 minutes and is anonymous. Your participation is completely voluntary. You can refuse to participate or stop the survey at any time without any negative effect on your relations with San José State University. If you participate, there are no anticipated risks to you and no anticipated benefits other than the satisfaction of sharing your views with the researchers. For more information about the study, contact Professor Asha W. Agrawal at asha.weinstein.agrawal@sjsu.edu. By agreeing to participate in the study, it is implied that you have read and understand the above information. Please do not write any identifying information on the survey/questionnaire.

This survey is about transportation in California: local streets and roads, state highways, and public transit services like buses, light rail, and trains.

Q1. In your community, how is the quality of each of the following?

\begin{tabular}{lccccc}
\hline & $\begin{array}{c}\text { Very good } \\
(\%)\end{array}$ & $\begin{array}{c}\text { Somewhat good } \\
(\%)\end{array}$ & $\begin{array}{c}\text { Somewhat bad } \\
(\%)\end{array}$ & $\begin{array}{c}\text { Very bad } \\
(\%)\end{array}$ & $\begin{array}{c}\text { Not sure / doesn't } \\
\text { apply (\%) }\end{array}$ \\
\hline Interstates, highways, and freeways & 19 & 49 & 22 & 7 & 3 \\
Local streets and roads & 12 & 41 & 33 & 13 & 1 \\
Bicycle and pedestrian facilities & 15 & 45 & 24 & 7 & 8 \\
Public transit (bus, rail, etc.) & 17 & 44 & 22 & 9 & 8 \\
\hline
\end{tabular}

Q2. How concerned are you about traffic congestion in your community?

\begin{tabular}{lc}
\hline & $\%$ \\
\hline Very concerned & 44 \\
Somewhat concerned & 42 \\
Not at all concerned & 14 \\
\hline
\end{tabular}


The next questions ask for your opinion about what government can do to improve transportation across all of California.

Q3. How important are the following transportation-related goals for California?

\begin{tabular}{lccc}
\hline & $\begin{array}{c}\text { Very important } \\
(\%)\end{array}$ & $\begin{array}{c}\text { Somewhat important } \\
(\%)\end{array}$ & $\begin{array}{c}\text { Not important } \\
(\%)\end{array}$ \\
\hline Reduce crashes and improve safety for everyone & 75 & 22 & 3 \\
$\begin{array}{l}\text { Reduce traffic congestion } \\
\text { Reduce health impacts caused by air pollution from } \\
\quad \text { cars and trucks }\end{array}$ & 71 & 26 & 3 \\
$\begin{array}{l}\text { Reduce greenhouse gas emissions from } \\
\quad \text { transportation sources that contribute to climate } \\
\quad \text { change }\end{array}$ & 58 & 30 & 7 \\
$\begin{array}{l}\text { Maintain and improve roads, streets, highways, and } \\
\text { bridges }\end{array}$ & 78 & 20 & 2 \\
$\begin{array}{l}\text { Make it more convenient to go places without driving } \\
\text { (bus, walking, bike, etc.) }\end{array}$ & 52 & 39 & 9 \\
\hline
\end{tabular}

Q4. As you may be aware, California charges a gas tax and spends the money collected for transportation. Listed below are different ways the state could spend that money to improve the transportation system. How much of a priority should each one be for the state?

\begin{tabular}{lcccc}
\hline & $\begin{array}{c}\text { High } \\
(\%)\end{array}$ & $\begin{array}{c}\text { Medium } \\
(\%)\end{array}$ & $\begin{array}{c}\text { Low } \\
(\%)\end{array}$ & $\begin{array}{c}\text { Not at all } \\
(\%)\end{array}$ \\
\hline Build/improve sidewalks & 41 & 38 & 18 & 3 \\
Subsidize public transit fares for low-income people & 42 & 34 & 17 & 8 \\
Develop programs that encourage people to switch from driving their cars & 35 & 38 & 20 & 7 \\
$\quad$ to walking, biking, or using transit & 33 & 35 & 22 & 10 \\
Provide financial incentives for people to purchase electric vehicles & 34 & 38 & 23 & 5 \\
Build/improve bike lanes and bike paths & 47 & 40 & 9 & 3 \\
Use advanced technologies to reduce congestion and increase reliability & 27 & 39 & 25 & 8 \\
Install more charging stations for electric vehicles & 40 & 39 & 17 & 4 \\
Add more frequent public transit service on existing routes & 46 & 37 & 14 & 4 \\
Expand public transit service into new areas not already served & 64 & 29 & 5 & 2 \\
Maintain local streets and roads & 43 & 39 & 14 & 3 \\
Build/widen local roads and streets & 48 & 35 & 14 & 3 \\
Build/widen interstates, highways, and freeways & 67 & 26 & 4 & 2 \\
Maintain interstates, highways, and freeways & & &
\end{tabular}


Q5. Here is the same list of transportation purposes that the state government could spend the gas tax money on. Select the three you think are most important.

\begin{tabular}{lc}
\hline & Selected as top 3 (\%) \\
\hline Build/improve sidewalks & 22 \\
Subsidize public transit fares for low-income people & 21 \\
Develop programs that encourage people to switch from driving their cars to walking, biking, & 17 \\
$\quad$ or using transit & 16 \\
Provide financial incentives for people to purchase electric vehicles & 11 \\
Build/improve bike lanes and bike paths & 26 \\
Use advanced technologies to reduce congestion and increase reliability & 9 \\
Install more charging stations for electric vehicles & 16 \\
Add more frequent public transit service on existing routes & 15 \\
Improve safety for pedestrians and bicyclists & 19 \\
Expand public transit service into new areas not already served & 45 \\
Fix local streets and roads & 15 \\
Build/widen local roads and streets & 22 \\
Build/widen interstates, highways, and freeways & 34 \\
Fix interstates, highways, and freeways & 2 \\
\hline
\end{tabular}

Q6. Many government agencies help to provide transportation infrastructure and services. In your community, how good a job do you think each one does?

\begin{tabular}{lccccc}
\hline & $\begin{array}{c}\text { Very good } \\
(\%)\end{array}$ & $\begin{array}{c}\text { Somewhat good } \\
(\%)\end{array}$ & $\begin{array}{c}\text { Somewhat bad } \\
(\%)\end{array}$ & $\begin{array}{c}\text { Very bad } \\
(\%)\end{array}$ & $\begin{array}{c}\text { Not sure / doesn't } \\
\text { apply (\%) }\end{array}$ \\
\hline $\begin{array}{l}\text { Caltrans (state highway department) } \\
\text { Public transit agencies (bus, rail, }\end{array}$ & 17 & 48 & 22 & 7 & 6 \\
$\quad$ etc.) & 18 & 46 & 22 & 8 & 6 \\
$\begin{array}{l}\text { City \& county governments (streets, } \\
\text { roads) }\end{array}$ & 14 & 40 & 30 & 11 & 4 \\
\hline
\end{tabular}

Q7. Imagine that the state plans to give people regular updates on how the gas tax money is spent in their county. For you personally, how useful would each of the following be for you as a way to receive updates?

\begin{tabular}{lccc}
\hline & $\begin{array}{c}\text { Very useful } \\
(\%)\end{array}$ & $\begin{array}{c}\text { Somewhat useful } \\
(\%)\end{array}$ & $\begin{array}{c}\text { Not useful at all } \\
(\%)\end{array}$ \\
\hline Caltrans provides monthly updates on a state website & 37 & 48 & 14 \\
$\begin{array}{l}\text { Annual DMV vehicle registration notices include a summary of } \\
\quad \text { how state transportation funds were spent the previous year }\end{array}$ & 44 & 43 & 13 \\
Caltrans send out monthly status updates via social media & 31 & 45 & 24 \\
I can sign up to get monthly emails that provide updates & 40 & 47 & 13 \\
\hline
\end{tabular}


Now we have a few questions about your personal transportation and how you get around.

Q8. What is the most recent time you used each type of transportation?

\begin{tabular}{lccc}
\hline & $\begin{array}{c}\text { Last 7 days } \\
(\%)\end{array}$ & $\begin{array}{c}\text { Last 30 days } \\
(\%)\end{array}$ & $\begin{array}{c}\text { Not used } \\
(\%)\end{array}$ \\
\hline Drive yourself (car, truck, motorcycle, etc.) & 79 & 7 & 14 \\
Ride as a passenger in a personal vehicle (exclude trips in taxis, & 50 & 24 & 26 \\
$\quad$ rideshare like Uber/Lyft, etc.) & 16 & 24 & 59 \\
Public transit (bus, train, ferry, etc.) & 5 & 12 & 83 \\
Taxi & 14 & 25 & 62 \\
Ridesharing services like Uber or Lyft & 50 & 23 & 28 \\
Walk to get somewhere (a store, work, friend's house, etc.) & 15 & 15 & 70 \\
Bicycle to get somewhere (a store, work, friend's house, etc.) & 7 & 9 & 84 \\
Electric kick-scooter, skateboard, or other small device & 6 & 5 & 89 \\
Other & & & \\
\hline
\end{tabular}

Q9. About how many miles did you, personally, drive during the past 12 months in all motorized vehicles? If you work, include the commute to and from work, but not any miles driven while on the job.

\begin{tabular}{ll}
\hline & $\%$ \\
\hline 1 to 3,000 miles & 24 \\
3,001 to 9,000 miles & 20 \\
9,001 to 13,000 & 19 \\
More than 13,000 miles & 18 \\
Don't drive & 19 \\
\hline
\end{tabular}

Q10. Now think about the vehicle you drove the most in the past 12 months, to get around for personal reasons like shopping, commuting to work, or vacation trips. How many miles per gallon does the vehicle get?

\begin{tabular}{lc}
\hline & $\%$ \\
\hline Less than $16 \mathrm{mpg}$ & 12 \\
17 to $21 \mathrm{mpg}$ & 16 \\
22 to $28 \mathrm{mpg}$ & 26 \\
29 to $43 \mathrm{mpg}$ & 19 \\
More than $43 \mathrm{mpg}$, including electric vehicle & 9 \\
Don't know & 19 \\
\hline
\end{tabular}

Q11. How would you describe the area where you live?

\begin{tabular}{lc}
\hline & $\%$ \\
\hline Urban part of a city/region & 36 \\
Suburban part of a city/region & 42 \\
Small town & 12 \\
Rural area & 9 \\
\hline
\end{tabular}




\section{ENDNOTES}

1. We report race and Hispanic ethnicity separately, in accordance with current practice at the U.S. Census Bureau.

2. Valerie M. Sue and Lois A. Ritter, Conducting Online Surveys, $2^{\text {nd }}$ edition (Sage Publications, 2012).

3. Monica Anderson, et al., " $10 \%$ of Americans Don't Use the Internet; Who Are They?" Pew Research Center, April 22, 2019, https://www.pewresearch.org/fact-tank/2019/04/22/ some-americans-dont-use-the-internet-who-are-they/.

4. Pew Research Center, "Collecting Survey Data" (no date), https://www.pewresearch. org/methods/u-s-survey-research/collecting-survey-datal.

5. Steven Ruggles, et al, "IPUMS USA: Version 10.0 [2013-2017 American Community Survey 5-Year Estimates]," Minneapolis, MN: IPUMS, 2020, https://doi.org/10.18128/ D010.V10.0.

6. For more information about the use of $p$-values in scientific research, see: American Statistical Association, "Statement on Statistical Significance and P-values," March 7, 2016, https://www.amstat.org/newsroom/pressreleases/P-ValueStatement.pdf.

7. Results of this analysis are not shown in table form in the report.

8. The difference between those finding it "somewhat useful" and "very useful" was statistically significant at $p<0.05$.

9. Steven Ruggles, et al. 


\section{ABBREVIATIONS AND ACRONYMS}

\begin{tabular}{ll}
\hline DMV & Department of Motor Vehicles \\
EV & Electric Vehicle \\
MPG & Miles per gallon \\
SB1 & Senate Bill 1 \\
\hline
\end{tabular}




\section{BIBLIOGRAPHY}

American Association for Public Opinion Research. "Response Rates: An Overview." http://www.aapor.org/Education-Resources/For-Researchers/Poll-Survey-FAQ/ Response-Rates-An-Overview.aspx.

American Statistical Association. "Statement on Statistical Significance and P-Values." March 7, 2016. https://www.amstat.org/newsroom/pressreleases/P_ ValueStatement.pdf.

Anderson, Monica, et al. "10\% of Americans Don't Use the Internet; Who Are They?" Pew Research Center. April 22, 2019. https://www.pewresearch.org/facttank/2019/04/22/some-americans-dont-use-the-internet-who-are-they/.

Kennedy, Courtney, and Claudia Deane. "What Our Transition to Online Polling Means for Decades of Phone Survey Trends." Pew Research Center. February 27, 2019. https://www.pewresearch.org/fact-tank/2019/02/27/what-our-transition-to-onlinepolling-means-for-decades-of-phone-survey-trends/.

Pew Research Center. "Collecting Survey Data.” No date. https://www.pewresearch.org/ methods/u-s-survey-research/collecting-survey-data/.

Ruggles, Steven, et al. "IPUMS USA: Version 10.0 [2013-2017 American Community Survey 5-Year Estimates]." Minneapolis, MN: IPUMS, 2020. https://doi. org/10.18128/D010.V10.0 (accessed June 2, 2019).

Sue, Valerie M., and Lois A. Ritter. Conducting Online Surveys, 2nd edition. Sage Publications, 2012. https://dx.doi.org/10.4135/9781506335186. 


\section{ABOUT THE AUTHORS}

\section{ASHA WEINSTEIN AGRAWAL, PHD}

Dr. Asha Weinstein Agrawal is the Director of the MTI National Transportation Finance Center and also Professor of Urban and Regional Planning at San José State University. Her research and teaching interests in transportation policy and planning include transportation finance, bicycle and pedestrian planning, and travel survey methods. She also works in the area of transportation history. She has a B.A. from Harvard University in Folklore and Mythology, an M.Sc. in Urban and Regional Planning from the London School of Economics and Political Science, and a Ph.D. in City and Regional Planning from the University of California, Berkeley.

\section{HILARY NIXON, PHD}

Dr. Hilary Nixon is Deputy Executive Director for the Mineta Transportation Institute. She specializes in transportation and environmental planning and policy, and her research focuses primarily on the factors that influence pro-environmental behavior and the relationship between transportation and the environment. In addition, she is a faculty member in the Master of Science in Transportation Management Program at San José State University. She earned a B.A. from the University of Rochester and a Ph.D. in Planning, Policy and Design from the University of California, Irvine.

\section{CAMERON SIMONS}

Cameron Simons is a graduate of the Master of Science in Data Analytics program at San José State University. His research interests focus on the use of big data analysis in transportation and the intersection between transportation and housing. 


\section{MTI BOARD OF TRUSTEES}

Founder, Honorable

Norman Mineta*

Secretary (ret.),

US Department of Transportation

\section{Chair,}

Abbas Mohaddes

President \& $\mathrm{COO}$

Econolite Group Inc.

\section{Vice Chair,}

\section{Will Kempton}

Executive Director

Sacramento Transportation Authority

\section{Executive Director,}

Karen Philbrick, PhD*

Mineta Transportation Institute

San José State University

\section{Winsome Bowen}

Chief Regional Transportation

Strategy

Facebook

\section{David Castagnetti}

\section{Co-Founder}

Mehlman Castagnetti

Rosen \& Thomas

\section{Maria Cino}

Vice President

America \& U.S. Government

Relations Hewlett-Packard Enterprise

\author{
Grace Crunican** \\ Owner \\ Crunican LLC
}

\section{Donna DeMartino \\ Managing Director \\ Los Angeles-San Diego-San Luis \\ Obispo Rail Corridor Agency}

\section{Nuria Fernandez**}

General Manager \& CEO

Santa Clara Valley

Transportation Authority (VTA)

\section{John Flaherty}

Senior Fellow

Silicon Valley American

Leadership Form

\section{William Flynn * \\ President \& CEO \\ Amtrak}

\section{Rose Guilbault}

Board Member

Peninsula Corridor

Joint Powers Board

Ian Jefferies*

President \& CEO

Association of American Railroads
Diane Woodend Jones

Principal \& Chair of Board

Lea + Elliott, Inc.

David S. Kim*

Secretary

California State Transportation

Agency (CALSTA)

\section{Therese McMillan}

Executive Director

Metropolitan Transportation

Commission (MTC)

\section{Bradley Mims}

President \& CEO

Conference of Minority

Transportation Officials (COMTO)

Jeff Morales

Managing Principal

InfraStrategies, LLC

Dan Moshavi, PhD*

Dean, Lucas College and

Graduate School of Business

San José State University

Toks Omishakin*

Director

California Department of

Transportation (Caltrans)
Takayoshi Oshima

Chairman \& CEO

Allied Telesis, Inc.

Paul Skoutelas*

President \& CEO

American Public Transportation

Association (APTA)

Beverley Swaim-Staley

President

Union Station Redevelopment

Corporation

Jim Tymon*

Executive Director

American Association of

State Highway and Transportation

Officials (AASHTO)

\section{Larry Willis*}

President

Transportation Trades

Dept.,AFL-CIO

$*$ = Ex-Officio

$* *=$ Past Chair, Board of Trustees

\section{Directors}

\section{Karen Philbrick, PhD}

Executive Director

\section{Hilary Nixon, PhD}

Deputy Executive Director

\section{Asha Weinstein Agrawal, PhD}

\section{Education Director}

National Transportation Finance

Center Director

\section{Brian Michael Jenkins}

National Transportation Security

Center Director

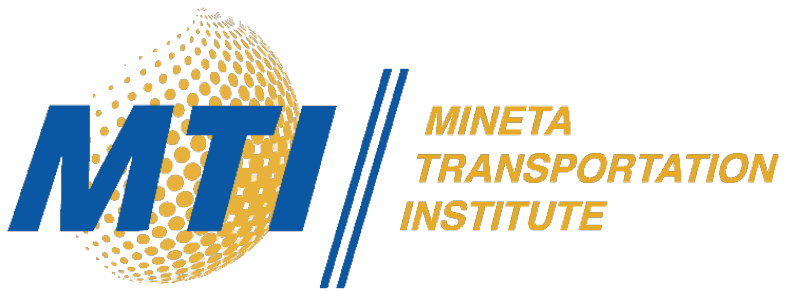

